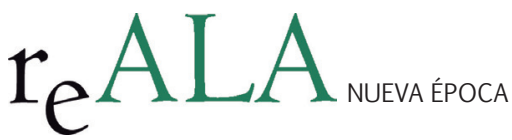

REALA, n 4, julio-diciembre 2015 ISSN: 1989-8975

DOI: http://dx.doi.org/10.24965/reala.voi4.10305

\title{
La función de regeneración democrática local de los funcionarios de habilitación con carácter nacional
}

\author{
Josep Ramon Fuentes i Gasó \\ Universitat Rovira iVirgili \\ josepramon.fuentes@urv.cat
}

Resumen

La reforma del régimen jurídico local conlleva la oportunidad de que los "funcionarios de Administración local con habilitación de carácter nacional", más allá de su rol tradicional de garantes de la legalidad, se conviertan en una suerte de curadores de la ética y la moralidad de la res publica de los entes locales en el Estado español, a través de lo que se denomina la "función de regeneración democrática" de las administraciones públicas. Este análisis se extiende a Italia, comparándose las soluciones que el ordenamiento jurídico italiano y el español dan a la probidad pública y a la lucha contra la corrupción.

Palabras clave

Corrupción. Integridad y ética públicas. Funcionarios con de carácter nacional. Reforma, racionalización y sostenibilidad. Administración local.

\section{The local democratic regeneration role of public officials with national qualification}

\section{Abstract}

The reform of local legal system involves the opportunity for the "local administration officials with national qualification" beyond its traditional role as guarantors of legality, to become a sort of curators of ethics and morality of the res publica of the local authorities in the Spanish State. It will be done through the so called "democratic regeneration function" of the government and public administrations. This analysis extends to Italy, comparing the solutions that the Italian legal system and the Spanish ones give to the public probity and to the fight against corruption.

Keywords

Corruption. Integrity and public ethics. Officials with national qualification. Reform, rationalization and sustainability. Local Government. 
“Esta llaga putrefacta de la sociedad es un grave pecado que grita hacia el cielo pues mina desde sus fundamentos la vida personal y social. La corrupción impide mirar el futuro con esperanza porque con su prepotencia y avidez destruye los proyectos de los débiles y oprime a los más pobres. Es un mal que se anida en gestos cotidianos para expandirse luego en escándalos públicos (... ). Corruptio optimi pessima, decía con razón San Gregorio Magno, para indicar que ninguno puede sentirse inmune de esta tentación. Para erradicarla de la vida personal y social son necesarias prudencia, vigilancia, lealtad, transparencia, unidas al coraje de la denuncia. Si no se la combate abiertamente, tarde o temprano busca cómplices y destruye la existencia."

FRANCISCUS, Misericordiae Vultus, Roma, $2015^{1}$

SUMARIO: I. INTRODUCCIÓN. II. LA NECESIDAD DE NUEVAS REFORMAS: UN AVANCE DESAFORTUNADO E INSUFICIENTE. III. LA APUESTA POR LA REGENERACIÓN DEMOCRÁTICA: UNA NUEVA CONCEPCIÓN DEL FUNCIONARIO LOCAL CON HABILITACIÓN NACIONAL. III.1. MARCO JURÍDICO DE REFERENCIA ANTERIOR A LA LRSAL. III.2. ¿CÓMO INCIDE LA REFORMA LOCAL EN EL ROL DEL FUNCIONARIO LOCAL CON HABILITACIÓN NACIONAL? III.3. LAS FUNCIONES PÚBLICAS NECESARIAS COMO FUNDAMENTO DE LA FUNCIÓN DE REGENERACIÓN DEMOCRÁTICA LOCAL. III.4. LA NUEVA ERA DE LA INTERVENCIÓN LOCAL. III.5. SECRETARIO, INTERVENTOR Y TESORERO FRENTE AL CUERPO POLÍTICO DE LAS ENTIDADES LOCALES: DESAJUSTE ENTRE LEGALIDAD Y REALIDAD. IV. EL SEGRETARIO COMO RESPONSABLE DE LA PREVENCIÓN DE LA CORRUPCIÓN LOCAL EN EL ORDENAMIENTO ITALIANO. IV.1. LA EMERGENCIA DE UN VERDADERO GARANTE DE LA LEGALIDAD Y DE LA PREVENCIÓN DE LA CORRUPCIÓN. IV.2. EL CÉNIT DEL SEGRETARIO COMUNALE Y PROVINCIALE. V. CONSIDERACIONES FINALES. VI. BIBLIOGRAFÍA

\section{INTRODUCCIÓN}

El desempleo y la corrupción pública se han consolidado como las mayores preocupaciones de los ciudadanos del Estado español según indican los resultados de los barómetros del $\mathrm{CIS}^{2}$. Crisis económica y crisis de la ética pública son conceptos interconectados, manifestaciones de fallos sistémicos que, utilizando las acertadas palabras de Juliana i Ricart, han llevado España a entrar en un estado de quiebra moral: "De las tres crisis que padece el país desde hace al menos siete años, la crisis económica, la crisis de Catalunya y la crisis de confianza en los partidos e instituciones, esta última comienza a ser, de largo, la más grave. La más difícil de solucionar y la que dificulta la mejora o reenfoque de las otras dos" 3 . Desde los escándalos de corrupción de la Costa del Sol y la icónica disolución del Ayuntamiento de Marbella en 2006 —-medida administrativa extrema sin parangón en nuestro ordenamiento jurídico ${ }^{4}$ - la percepción de la corrupción en España ha pasado de un deterioro paulatino a un empeoramiento repentino. En el año 2000 los datos elaborados por Transparency International situaban el país en la posición 20 del Índice de Percepción de la Corrupción, con una nota de 7 sobre 10. En cambio, en la última edición de 2014, España se encuentra en el lugar 37 y una nota de 6; esto supone incremento de la corrupción percibida en un dramático 100\%, habiéndose registrado la caída a partir del 2008, año de inicio de la crisis económica, en la que España baja de la posición 23 a la 28 y a partir de ahí hasta la fecha de hoy acelera su precipicio. Así en 2011, es "nuestro gran reto del momento" 5 . La ininterrumpida cadena de escándalos en todos los niveles y a lo largo de toda la geografía española, desde el "Caso Innova" en el Ayuntamiento de Reus, hasta la más reciente "Operación Púnica" ${ }^{\circ}$ que ha desvelado un entramado delictivo en la Comunidad de Madrid, nos lleva a dos consideraciones: la primera es reconocer la necesidad de que la cuestión de la integridad pública se presenta de manera ineludible como uno de los temas fundamentales a tratar por el derecho del siglo $\mathrm{XXI}^{7}$ y, la segunda, que la complejidad del fenómeno ha

1 FRANCISCUS, Misericordiae Vultus, Bula de convocatoria del Jubileo Extraordinario de la Misericordia, Roma, 11 de abril de 2015 núm. 19, pág. 12.

2 Vid. Centro de Investigaciones Sociológicas (CIS), Barómetros, disponibles en http://www.cis.es/cis/opencm/ES/11_barometros/ index.jsp.

3 JULIANA I RICART, E., “La quiebra moral”, La Vanguardia, 28/10/2014, disponible en http://www.Iavanguardia.com/ politica/20141028/54418335591/quiebra-moral-enric-juliana.html.

4 Vid. in totum, PÉREZ-FRANCESCH, J. L., COCCIOLO, E., EYRE de LORENZO, J. A., “Disolución de los Ayuntamientos en España y corrupción sistémica. Aproximación al 'Caso Marbella' y comparación con la normativa italiana en materia de disolución en supuestos de emergencia extraordinaria”, Revista de Estudios de la Administración Autonómica y Local (REALA), núm. 305, 2007, págs. 299-324.

5 Vid. los índices de percepción de la corrupción desde 1995, http://www.transparency.org/research/cpi/.

6 Vid. http://elpais.com/tag/innova_grup_empreses_municipals_reus/a/; http://elpais.com/tag/operacion_punica/a/

7 Vid. PICADO SOTELA, S., "Ética pública y corrupción” en AA.VV., El derecho público a comienzos del siglo XXI. Libro Homenaje al Prof. Brewer Carías, Thomson-Civitas, Madrid, 2003, III, pág. 3377 y ss. 
alcanzado la condición de corrupción sistémica ${ }^{8}$, equiparable a la denominada Tangentopoli italiana o "Sociedad del soborno", para nosotros.

Frente a este panorama, resulta patente que las medidas anticorrupción previstas por el Derecho Penal son insuficientes, además de ser insatisfactorias y reflejar una prevención administrativa débil 9. Al contrario, en el ámbito del Derecho Administrativo es donde encontramos el conjunto de incentivos y desincentivos destinados a garantizar el correcto funcionamiento de los mercados, de los sectores económicos y de la rectitud de las conductas de los actores implicados, así como los elementos determinantes del control, de la supervisión y de las garantías dirigidas a asegurar el servicio a los intereses generales ${ }^{10}$.

Ahora bien, cabe destacar que el deterioro de la integridad pública no es algo que ocurra en España de forma exclusiva ${ }^{11}$. Los datos sobre corrupción y la consecuente desafección política de la sociedad son comunes en todos los países de Europa; pero en particular en el sur. La cercanía cultural y jurídica con Italia, salvas las particularidades de cada uno de ambos Estados, nos resulta de gran utilidad en el entendimiento de las medidas necesarias de lucha contra la corrupción.

A pesar de ello, esta suerte de "pandemia de carácter mundial” que es la corrupción, alcanza proporciones mundiales en mayor o menor grado, lo que le ha garantizado un puesto destacado en la agenda normativa de las grandes organizaciones internacionales. En este sentido, el Consejo de Europa promovió en 1999 el Convenio penal sobre la corrupción ${ }^{12}$ y a la Organización de Naciones Unidas (ONU) la Convención contra la corrupción, por destacar lo más importantes ${ }^{13}$, que persiguen la implantación de una verdadera "culture of integrity" que, para la OCDE, "requires coherent efforts to update standards, provide guidance, and monitor and enforce them in daily practice. It also requires countries to anticipate risks and apply tailored countermeasures. These include specific guidelines or restrictions, increased transparency or tightened control, and enforceable sanctions" ${ }^{14}$.

Se ha reiterado que la corrupción es la expresión más grave de la falta de ética pública, concepto consagrado en nuestro sistema jurídico por el Prof. González Pérez ${ }^{15}$. En ese sentido, Villoria y Jiménez ${ }^{16}$ afirman que la corrupción afecta negativamente al funcionamiento de la democracia y el Estado de Derecho al dañar la igualdad política y el bien común. De tal modo que resulta inaplazable la aplicación de medidas de máxima transparencia y rendición de cuentas, así como el refuerzo de los valores que deben caracterizar y orientar la gestión pública para recuperar la confianza y el prestigio político y burocrático, tan dañado por sí mismo y por la instigación constante de los medios de comunicación.

En esta línea, se debe apostar por una normativa a favor de la integridad pública y la transparencia, y por unos instrumentos de supervisión implacables y rigurosos. En muchas ocasiones se ha criticado el régimen de

8 La corrupción alcanza un grado sistémico cuando la máquina del desgobierno y de la degradación no sólo "automantiene ma si espande diffusivamente, produce propri incentivi alle deviazioni collusive e diviene un processo cumulativo che tende a generalizzarsi fino al punto in cui tutti i corrompibili diventano corrotti, mentre tutti gli altri si ritirano dal 'mercato", BELLIGNI, S., "Corruzione, malcostume amministrativo e strategie etiche. II ruolo dei codici”, en Working Papers del Departamento de Ciencias Políticas «Polis», Universidad del Piemonte Oriental «Amedeo Avogadro», Torino, 1999, pág. 18 www.al.unipmn.it/ segrsp/Fac_Scienze_Politiche_II/pubbl/index.html.

9 Desde un punto de vista teórico, sobre la insuficiencia del derecho penal y la implementación de estratégicas de regulación administrativa contra la corrupción, COCCIOLO, E. E., “Las mutaciones del concepto de corrupción. De la ambigüedad de las sociedades arcaicas a la complejidad en la época del Estado regulador y de la sociedad del riesgo”, Revista de Llengua i Dret, núm. 50, 2008, pág. 21 y ss.

10 Así, se resalta el valor de las instituciones de Derecho Administrativo como las herramientas más idóneas para prevenir la corrupción en RIVERO ORTEGA, R., Instituciones administrativas, desarrollo y control de la corrupción. El caso colombiano, Unión Iberoamericana de Municipalistas, Madrid, 2006, págs. 24-25.

11 Vid. BRIOSCHI, C. A., Breve storia della corruzione dall'età antica ai giorni nostri, Tea, Milán, 2004.

12 Convenio penal sobre corrupción (Convenio núm., 173), hecho en Estrasburgo el 27 de enero de 1999 (Boletín Oficial del Estado, BOE, núm., 182, de 28 de julio de 2010), y que entró en vigor el 1 de septiembre de 2010. Este instrumento ha sido completado mediante el Protocolo adicional al Convenio penal sobre corrupción, hecho en Estrasburgo el 15 de mayo de 2003 (BOE, núm. 56, de 7 de marzo de 2011), y que entró en vigor el 1 de mayo de 2010. Y, finalmente, cabe citar el Convenio civil sobre corrupción (Convenio núm., 174), hecho en Estrasburgo el 4 de noviembre de 1999 (BOE, núm., 78, de 31 de marzo de 2010), y que entró en vigor el 1 de abril de 2010.

13 Convención contra la corrupción de ONU hecha en Nueva York el 31 de octubre de 2003 (BOE, núm. 171, de 19 de julio de 2006), entra en vigor el 19 de julio de 2006.

14 Organización par la Cooperación y el Desarrollo Económicos (OCDE), Government at a Glace 2009, pág. 15, disponible en: http:// www.oecd.org/gov/43926778.pdf.

15 "El conjunto de normas morales que rigen la conducta del hombre en cuanto integrante de un pueblo o ciudad —en cuanto ciudadano, sea o no funcionario, y en orden al bien común, bien público o bienestar general” GONZÁLEZ PÉREZ, J., La ética en la Administración Pública, 2a. ed., Madrid, Civitas, 2000, pág. 40. En cualquier caso, "la ciudadanía maneja una idea sencilla pero bastante correcta de lo que es la corrupción, y la identifica como conducta torcida que obedece a que el inmoral funcionario —el protagonista habitual- sirve por dinero a los intereses de quién le paga”. QUINTERO OLIVARES, G., FRANQUET SUGRAÑES, M. T., "Estado, mercado y Constitución: la dimensión penal”, en QUINTERO OLIVARES, G., (dir.), JARIA MANZANO, J., (coord.), Derecho Penal Constitucional, Tirant lo Blanch, Valencia, 2015, pág. 505.

16 VILLORIA MENDIETA, M.; JIMÉNEZ SÁNCHEZ, F., “La corrupción en España (2004-2010): datos, percepción y efectos”, REIS, núm. 138, abril-junio 2012, pág. 110. 
los controles aplicables a las entidades locales (EELL) ${ }^{17}$, lo que acaba derivando en un escenario de aparente permisividad e impunidad de ciertas conductas reprochables. Superar la "visión corruptogénica" de las administraciones locales y recuperar su rol insoslayable en la construcción de un sistema de alta calidad de vida para todos los ciudadanos, es una tarea fundamental de la acción política y del derecho público actual ${ }^{18}$. En este contexto han venido sucediéndose una serie de reformas a lo largo de los últimos años con el objetivo de paliar todos estos efectos negativos e intentar que la situación, como mínimo, no empeore. Es aquí donde entra en escena la nueva reforma del régimen local actual del gobierno español a través de la aprobación de la Ley 27/2013, de 27 de diciembre, de Racionalización y Sostenibilidad de la Administración Local ${ }^{19}$ (LRSAL) ${ }^{20}$ que viene a modificar la Ley 7/1985, de 2 de abril, Reguladora de las Bases del Régimen Local (LRBRL). Una propuesta que pretende, en último término, mejorar el control económico-financiero de las Administraciones locales haciendo uso del secretario, interventor y tesorero ${ }^{21}$ — "funcionarios de administración local con habilitación de carácter nacional” (FHN)—, convertidos en una suerte de tutores estatales de los EELL 22, otorgándoles el papel de guardianes de la "buena administración" ${ }^{23}$ y/o el "buen gobierno" ${ }^{24}$. Ahora bien, como afirma Arias Díaz, "no hay políticos corruptos sin funcionarios permisivos", por lo que hay que centrarse en los funcionarios por ser los principales contribuyentes a esta situación, al permitir por acción u omisión la adopción de acuerdos ilegales, en fraude de ley o contrarios a los más elementales principios éticos ${ }^{25}$.

17 Vid. diversos casos en URQUIZA MORALES, J. M., Corrupción municipal. Por qué se produce y cómo evitarla, Almuzara, Córdova, 2005; o desalentadores datos en GONZÁLEZ LÓPEZ-VALCÁRCEL, B., JIMÉNEZ GONZÁLEZ, J. L., PERDIGUERO GARCÍA, J., Danger: local corruption is contagious!, Mimeo, 2014. La importancia de la función de control en relación a la materialización del derecho a la buena administración ha sido analizada por COCCIOLO, E. E. et al., “Els controls i la bona administración”, en MOLES PLAZA, R. J., y COCCIOLO, E. E., Anàlisi dels elements del bon govern local. Codi del bon govern local, ACM, Barcelona, 2011, págs. 16-17.

18 Ibidem, págs. 16-17.

19 La LRSAL ha sido objeto de diversos estudios y comentarios. Señalamos, por orden cronológico los siguientes: GARCíA RUBIO, F. (dir.) Análisis de las repercusiones de la reforma local sobre la organización, competencias y servicios de las entidades locales, Instituto Nacional de Administración Pública (INAP), Madrid, 2015; GUTIÉRREZ COLOMINA, V., LLAVADOR CISTERNES, H., (coord.), Ley de Racionalización y Sostenibilidad de la Administración Local. Estudio sobre la aplicación de la ley 27/2013, de 27 de diciembre, Tirant lo Blanch, Valencia, abril, 2015; AAVV, La revisión del Gobierno y la Administración local en la Ley 27/2013, Cuadernos de Derecho Local (QDL), núm. 34 extraordinario, Fundación Democracia y Gobierno Local, Madrid, febrero, 2014; CARRILLO DONAIRE, J. A., NAVARRO RODRÍGUEZ, P., La reforma del régimen jurídico de la administración local. El nuevo marco regulatorio a la luz de la ley de racionalización y sostenibilidad de la administración local, La ley-El Consultor, Madrid, 2014; CEBRIÁN ABELLÁN, M., El régimen local tras la reforma de la Ley de racionalización y sostenibilidad, Bosch -Wolters Kluwer, 2014; FONT LLOVET, T., GALÁN GALÁN, A. (dirs.), Anuario del Gobierno Local 2013 ¿Un nuevo gobierno en España? La reforma de la Administración local en la Ley 27/2013, Fundación Democracia y Gobierno Local, Barcelona, junio, 2014; FORCADELL ESTELLER, X., PIFARRÉ ESTRADA, M., SABATÉ I VIDAL, J. M. (coords.), Els governs locals de Catalunya davant la reforma del règim local espanyol, Parlament de Catalunya, Barcelona, 2014; MEDINA GUERRERO, M., La reforma del régimen local, Tirant lo Blanch, Valencia, 2014; MELLADO RUíz, L., Génesis y realidad de la ley 27/2013, de 27 de diciembre, de racionalización y Sostenibilidad de la administración local:¿una nueva reforma económica local?, Centro de Estudios Municipales y de Cooperación Internacional (CEMCI), Granada, 2014; QUINTANA LÓPEZ, T. et alter, La reforma del régimen local. Comentario a la ley 27/2013, de 27 de diciembre, de racionalización y sostenibilidad de la administración local, Tirant lo Blanch, Valencia, 2014; RODRÍGUEZ-ARANA MUÑOZ, J., SARMIENTO ACOSTA, M. J., (dirs.), Comentarios a la Ley27/2013, de 27 de diciembre, de racionalización, sostenibilidad de la administración local, Comares, Granada, 2014; SANTAMARÍA PASTOR, J. A., (coord.), La reforma de 2013 del régimen local español, Fundación Democracia y Gobierno Local, Madrid, 2014; y FORCADELL I ESTELLER, X., SABATÉ I VIDAL, J. M., (coords.), La reforma local. Reptes i oportunitats davant dels projectes de reforma del règim local impulsats pel govern estatal i el govern de la Generalitat, Barcelona, 2013.

20 En este sentido, como análisis reciente de la aplicación de la LRSAL, vid. RIVERO ORTEGA, R., "Oportunidades, riesgos y resultados reales de la Ley de racionalización y sostenibilidad de la Administración Local” en REALA, núm. extraordinario, enero, 2015 y FUENTES I GASÓ J., R., "Consecuencias de la Ley 27/2013, de Racionalización y Sostenibilidad de la Administración Local en el régimen local de Cataluña", Revista Vasca de Administración Pública (RVAP), núm. 101, abril-mayo 2015, págs. 55-88.

21 A lo largo del texto las referencias al género masculino se deben entender referidas también al género femenino.

22 En relación con el nuevo rol que juegan los FHN, vid. in totum, MONTALBO LOBO, L., "La nueva posición de los funcionarios de administración local con habilitación de carácter nacional”, en RODRíGUEZ-ARANA MUÑOZ, J., SARMIENTO ACOSTA, M. J., (dirs.), op. cit., págs. 201-236.

23 Así, “la buena administración supone la obligación de resolver en la forma más adecuada atendiendo a las circunstancias y los hechos determinantes y los diferentes intereses implicados, no sólo atendiendo a los principios de eficiencia y eficacia —como muy a menudo se han manifestado los paladines de la nueva gestión pública一; si no también al principio de legalidad administrativa. Así mismo, administrar bien no sólo es producir buenas resoluciones administrativas (...) y prestar buenos servicios (...); sino que toda decisión o actuación administrativa tiene que estar presidida también por el principio de transparencia”. FUENTES I GASÓ, J. R., "Buenas prácticas y códigos de conducta: ¿Sustitutivos de la legislación?”, Speyerer Forchungsbericte, núm. 201, 2015, págs. 144-145. Asimismo, “es la que demanda y exige la sociedad actual, la única políticamente respetable. (...) en todo caso, el objetivo de servicio al interés general, desde el respeto a los derechos y la dignidad de las personas tendrá que ser la regla inviolable”. QUINTERO OLIVARES, G., FRANQUET SUGRAÑES, M. T., op. cit, pág. 495. Vid. in totum, RODRÍGUEZ-ARANA MUÑOZ, J., "El derecho a la buena administración en las relaciones entre ciudadanos y administración pública”, Anuario da Facultade de Dereito da Universidade da Coruña (AFDUC), núm. 16, 2012, págs. 247-273; ÁVILA RODRíGUEZ, C. M., GUTIÉRREZ RODRÍGUEZ, F. (coords.) El derecho a la buena administración y la ética pública, Tirant lo Blanch, Valencia, 2011.

24 "El buen gobierno se refiere a una esfera más doméstica de la Administración en el sentido de que son todas aquellas normas que, de un modo u otro, corresponden a las prescripciones éticas que han de guiar la conducta de los empleados públicos”. FUENTES I GASÓ, J. R., "Buenas prácticas...", op. cit., pág. 147.

25 ARIAS DÍAZ, I., "Chequeo a la Administración pública y propuesta de código ético y de buenas prácticas”, Revista jurídica de Asturias, núm. 35, 2011, pág. 97-98. Así, “el punto más alejado de la 'buena Administración' es la 'Administración corrupta', si bien es importante hacer una cierta precisión. En una 'buena Administración' puede haber casos de funcionarios corruptos, y para poder 
En este punto, resultará especialmente interesante proceder al análisis de la reforma llevada a cabo en Italia a través de la llamada "Ley Severino" ${ }^{26}$, en donde el segretario se transforma ope legis en "responsable de la prevención de la corrupción" en las EELL y, con ello, en el puntal de "regeneración democrática" del mundo local por lo menos hasta su abolición y transformación en directivos de las corporaciones locales, a la luz de la próxima supresión del "corpo segretari comunali e provinciali” prevista por la Legge 7 agosto 2015, núm. 124.

Ahora bien, volviendo al tema que nos ocupa, cabe observar que, si de una parte, las citadas reformas, de ser bien aplicadas pueden suponer un cambio en la gestión de los riesgos de la corrupción; de otra, no implican una novedad absoluta a nivel internacional. Se trata, pues, de medidas a todas luces comparables, por ejemplo, con el modelo norteamericano del ethics officer, un directivo público —normalmente coincidente con el letrado — asesor de entidad u organización-cuya principal responsabilidad es mejorar la actuación ética de la organización y asegurar el cumplimiento de la normativa aplicable en materia de integridad pública. En ese sentido, Izraeli y BarNir apuntaron que "this involves advising management on the development of codes, preparing ethics training programs, monitoring compliance with the codes, and taking remedial action in case of inappropiate behaviour by members of the organization" ${ }^{27}$. Un "agente público" que ha florecido precisamente en un modelo institucional, el norteamericano, en el que la regulación de la ética administrativa supone "una de las claves del dinamismo y de la innovación política jurídica e institucional”, tal como señala el Prof. Ballbé Mallol ${ }^{28}$. Sin embargo, la implantación de órganos como éste no puede hacerse sin más, sino que debe adaptarse a las particularidades de cada sistema y no empezar a condicionar económicamente la prestación de servicios públicos de forma tan estricta como la propuesta por la reforma, cuyas medidas llevan aparejado, en algunos casos, el ánimo de privatización de los servicios, evitando el debate público que merecen ${ }^{29}$. En esta línea, pero desde una perspectiva economicista, la LRSAL aumenta la responsabilidad de los FHN, al otorgarles un conjunto de funciones que antes no poseían, con el claro objetivo de dar cumplimiento a la estabilidad presupuestaria y la sostenibilidad financiera consagradas en la reforma del art. 135 de la Constitución española $(C E)^{30}$.

Ahora bien, dejando a un lado estos significativos cambios, no todas las medidas que incorpora la LRSAL deben abrazarse con entusiasmo, ni mucho menos. La Ley adolece de serios problemas, tanto conceptuales, como de aplicación práctica que han suscitado una gran polémica entre la doctrina ${ }^{31}$, los profesionales implicados y el mundo local en general. Algunos de los defectos más evidentes son la falta de una voluntad real de cambiar la cultura administrativa de empleados públicos e instituciones, una intención clara de vaciar de competencias a las Administraciones locales y la recentralización de muchos aspectos en contra de la autonomía local ${ }^{32}$. Así, para Parejo Alfonso, "la Ley puede valorarse cuando menos como comienzo de un proceso recentralizador que tiene como guía una sustancial dilución de la qualitas del autogobierno local mediante la infusión de una generosa

llegar a hablar globalmente de corrupción referida a toda la Administración, o su mayoría, habría que ir a casos de estados que viven permanentemente en crisis institucional”. QUINTERO OLIVARES, G., FRANQUET SUGRAÑES, M. T., op. cit., pág. 494.

26 Vid. post, en capítulo IV, el análisis exhaustivo de la Legge 6 novembre 2012, n. 190. Disposizioni per la prevenzione e la repressione della corruzione e dell'illegalità nella pubblica amministrazione (Ley 190/2012).

27 IZRAELI, D., BAR NIR, A., "Promoting ethics through Ethics Officers: a proposed profile and an application”, Journal of Business Ethics, núm. 17, 1998, pág. 1989.

28 BALLBÉ MALLOL, M., "El futuro del Derecho Administrativo en la globalización: entre la americanización y la europeización”, Revista de Administración Pública (RAP), núm. 174, Madrid, septiembre-diciembre 2007, pág. 245.

29 Vid. BRUGUÉ TORRUELLA, J., GALLEGO CALDERÓN, R., “Actituds i habilitats en els gerents públics (locals) del segle XXI”, en Repensar el paper del gestor públic en el segle XXI. Actes del I Congrés Català de Gestió Pública, Escola d’Administració Pública de Catalunya (EAPC), Barcelona, 2003, pág. 192-193.

30 Desarrollado por la Ley Orgánica 2/2012, de 27 de abril, de Estabilidad Presupuestaria y Sostenibilidad Financiera. Un decisión legislativa aplaudida por la representación estatal del colectivo, "por fin los responsables políticos se han ido concienciando de la necesidad de reforzar una escala de funcionarios altamente cualificados, responsables, independientes, objetivos y sobre todo con una mentalidad de defensa de los intereses generales a prueba de toda duda". ÁVILA CANO, E., "Democracia y gobierno local: La aportación de los secretarios, interventores y tesoreros de la Administración Local a su historia reciente”, en ORDUÑA REBOLLO, E., MERINO ESTRADA, V. (coord.), Secretarios, interventores y tesoreros de la administración local: doscientos años al servicio de la ciudadanía, Consejo General de Colegios de Secretarios, Interventores y Tesoreros de Administración Local (COSITAL), Madrid, 2012, pág. 363.

31 De forma implacable, ZAFRA VíCTOR, M., “Esta reforma local empobrece la democracia”, El País, 1 de agosto de 2013 , donde afirma que "resulta desolador comprobar que las entidades locales solo cobran relevancia política con motivo de la estabilidad presupuestaria. El proyecto de ley aprobado en Consejo de Ministros culmina un proceso de marginación política del gobierno local en el Estado de las autonomías degradando a una materia o actividad, objeto de la disputa competencial entre Estadio y CA". Vid. JIMÉNEZ ASENSIO, R., "EI Proyecto de ley de Racionalización y Sostenibilidad de la Administración Local: novedades más relevantes en relación con los borradores del ARSAL y principales enmiendas aprobadas en el Congreso de los Diputados" (I y II), Diario del Derecho Municipal, 27 y 28 de noviembre de 2013 o NAVARRO RODRÍGUEZ, P., ZAFRA VÍCTOR, M., "El pretendido blindaje autonómico de las competencias municipales tras la reforma de la Administración local”, REALA, núm. 2, julio-setiembre, 2014, pág. 3, para quiénes “cabe inferir que el propósito de la LRSAL pasa por la eliminación virtual de la autonomía municipal”.

32 Con todo ello "queda devaluada la garantía constitucional de la autonomía local”. SALAZAR BENíTEZ, O., “La autonomía local devaluada: La dudosa 'racionalidad' de la Ley 27/2013, de 27 de diciembre, de racionalización y sostenibilidad de la Administración local”, Teoría y Realidad Constitucional, UNED, núm.34, 2014, pág. 374. 
dosis de mera quantitas, con seria afección de la sustancia democrática de aquel"33. El vaciamiento competencial del mundo local supone optar por la solución más simple, en lugar de aplicar una alternativa en las relaciones interadministrativas más coherente con las necesidades del modelo social actual ${ }^{34}$. "En definitiva, hay que trasladar el centro de gravedad del sistema competencial desde la administración al ciudadano, que es el destinatario”35.

El mundo local es la clave para conseguir la necesaria regeneración democrática de la que tanto se está hablando recientemente, y cuyas medidas propuestas por el Gobierno del Estado se alejan de una voluntad real con esta finalidad. Se está desaprovechando una gran oportunidad de refundar realmente la Administración local, pues el discurso que preside esta ola de transformación ética se aparta de la vertiente más pragmática y realista y parece que persigue más intereses electoralistas que no de buen gobierno y buena administración. Y, es "que no es nada fácil 'racionalizar' la Administración local”"36.

El presente estudio intenta abordar el análisis crítico y comparado de las recientes modificaciones normativas española e italiana relacionadas con la lucha contra la corrupción y la apuesta por la regeneración democrática. A pesar de ello, no se analizarán las modificaciones más significativas que establece la LRSAL y las múltiples reformas del gobierno local perpetradas en Italia; sino que nos centraremos de forma más intensa en esa lucha, cuya piedra angular se sustenta en la potenciación de la independencia y las funciones de estos empleados locales sui generis como verdaderos órganos administrativos garantes de la legalidad y el buen gobierno, en un panorama de aparente relajación de la ética y la moralidad públicas, en particular, en ámbito local, causada, en gran parte, por el “milagro" económico de la España de la primera década del siglo XXI y su equivalente italiano ${ }^{37}$.

\section{LA NECESIDAD DE NUEVAS REFORMAS: UN AVANCE DESAFORTUNADO E INSUFICIENTE}

La situación de crisis en la que nos hallamos inmersos desde el 2008 ha generado graves consecuencias económico-financieras para las arcas públicas, hecho que ha obligado a tomar una serie de medidas dirigidas a la contención presupuestaria en prácticamente todos los ámbitos ${ }^{38}$. Una de estas medidas ha sido potenciar el papel de los FHN, como una suerte de déjà vu, de retorno al "rol vicarial” del Gobierno del Estado, propio de otros tiempos39.

La modificación de la LRBRL que nos ocupa, mediante la LRSAL, pretende aplicar los principios de estabilidad presupuestaria y sostenibilidad financiera ${ }^{40}$, eje central entorno al cual se estructura la reforma

33 PAREJO ALFONSO, L., "Algunas reflexiones sobre el impacto de la Ley 27/2013, de 27 de diciembre, sobre el modelo de autogobierno municipal”, Cuadernos de Derecho Local (QDL), núm. extraordinario, op. cit., pág. 14.

34 EI CONSEJO DE EUROPA, Informe sobre la democracia local y regional en España, aprobado en la 24. ${ }^{a}$ sesión plenaria, Estrasburgo, 20 de marzo de 2013, advierte de que "existe, sin embargo, un riesgo específico de reducción de la autonomía local por lo que respecta a la supervisión financiera del gobierno central”, parágrafo 239, pág. 47.

35 La delimitación autonómica y la provincial, sumadas al exceso de instancias administrativas municipales e inframunicipales, genera una confusión de ámbitos de actuación entre los distintos niveles de gobierno, derivando en un modelo poco racional. Y, continua, "así, el mapa competencial no tendría que venir determinado por quien ejerce una competencia o realiza una determinada actividad efectivamente, sino por quien la puede ejercer más adecuadamente, es decir logrando un mayor grado de calidad y satisfacción de la ciudadanía, con mayor eficiencia y eficacia”. FUENTES I GASÓ, J. R., “Consecuencias de la Ley 27/2013, ...”, op. cit., pág. 85.

36 Así, "la Ley, por tanto, sigue plenamente vigente, demostrando sus inefectividades que para las grandes reformas es preferible el consenso a la unilateralidad. Que cuando no se plantean en términos positivos, sino bajo la presión de una extrema urgencia, no persisten en el tiempo. Que en España los municipios son anteriores al Estado, a las Comunidades Autónomas y a las Diputaciones provinciales. Que la autonomía es fuerte y resistente por sus bases democráticas.” RIVERO ORTEGA, R., “Oportunidades, riesgos y resultados reales...”, op. cit., pág. 8.

37 Así se expresa JIMÉNEZ GONZÁLEZ, J. L., “La corrupción local en España”, Cuadernos económicos de ICE, núm. 85, junio, 2013 , pág. 39.

38 Parejo Alfonso señala que una de las primeras reformas orientadas a este fin fue la aprobación del Real Decreto-Ley $7 / 2012$, de 9 de marzo, por el que se crea el Fondo para la financiación de los pagos a proveedores. Esta norma obliga a las EELL a llevar a cabo un plan de ajuste, cuya aprobación requiere el informe favorable del interventor municipal. Es más, las que concierten operaciones de endeudamiento, deberán presentar de forma anual o trimestral un informe del mismo interventor al MHAP, encargado de valorarlo para dar cuenta al Ministerio de Economía y Competitividad. Asimismo, el Real Decreto-ley 4/2012, de 24 de febrero, por el que se determinan obligaciones de información y procedimientos necesarios para establecer un mecanismo de financiación para el pago a los proveedores de las EELL, incorpora una serie de obligaciones que refuerzan el papel de control económico llevado a cabo por el interventor municipal. PAREJO ALFONSO, L., "El principio de legalidad, la Administración local y las funciones públicas colocadas en ella al servicio de aquél”, en ORDUÑA REBOLLO, E., MERINO ESTRADA, V. (coord.), op. cit., pág. 459.

39 Vid. Informe sobre el nuevo Régimen jurídico de los Funcionarios de Administración Local con Habilitación de carácter Nacional, establecido en la Ley 27/2013, de 27 de diciembre, INAP, Ministerio de Hacienda y Administraciones Públicas (MHAP), Madrid, 28 de mayo de 2015. Disponible en: http://www.famp.es/famp/programas/seminarios_cursos_jornadas/14_AdmonLoc/informe.pdf. El colectivo en Cataluña no aplaudía con tanto fervor la LRSAL puesto que ha hecho recaer en él "la tasca d'interpretar les previsions jurídiques contingudes a la normativa vigent, tant general com sectorial, i dotar de seguretat jurídica a les decisions que els diferents òrgans de govern municipals han anat adoptant fins el moment per salvaguardar al màxim les competències locals". CSITAL Barcelona, Compromesos amb l'autonomia local, Declaración de la Asamblea de Sant Cugat el Vallès, 28 de noviembre de 2014, http://www.csital.org/declaracions/2014/compromesosautonomia-local.php.

40 Consagrados en el art. 135 CE reformado y en la Ley Orgánica 2/2012, de 27 de abril, de Estabilidad Presupuestaria y Sostenibilidad Financiera. 
de la Administración local, con la finalidad de adaptar algunos aspectos de su organización y funcionamiento y mejorar su control económico-financiero ${ }^{41}$. Para ello, el preámbulo de la Ley afirma seguir cuatro líneas principales de actuación: "clarificar las competencias municipales para evitar duplicidades con las competencias de otras administraciones de forma que se haga efectivo el principio ‘una Administración una competencia' ${ }^{22}$, racionalizar la estructura organizativa de la Administración local de acuerdo con los principios de eficiencia, estabilidad y sostenibilidad financiera ${ }^{43}$, garantizar un control financiero y presupuestario más riguroso ${ }^{44}$ y favorecer la iniciativa económica privada evitando intervenciones administrativas desproporcionadas" ${ }^{45}$. Y por último, se podría añadir la profesionalidad y transparencia en la gestión pública local y el reforzamiento de la independencia de los $\mathrm{FHN}^{46}$.

Ahora bien, como ya se ha expuesto, la LRSAL, por su envergadura focalizada únicamente en el ámbito local y de una intensidad que no se plantea en ningún otro nivel administrativo y por su falta de transversalidad, no está exenta de polémica, y algunas voces han mostrado su desconfianza sobre la efectividad real. Una iniciativa que ha sido objeto de severas críticas esencialmente por su más que dudoso respeto a la garantía institucional de la autonomía local consagrada en la CE ${ }^{47}$. Así, para Salazar Benítez, "supone un significativo paso adelante en la configuración de los Ayuntamientos como meros prestadores de servicios y en su devaluación como entidades articuladas constitucionalmente sobre los principios de autonomía y democracia. En este sentido, hay una clara negación del contenido que a la autonomía local se le otorga en la Carta Europea de Autonomía Local” ${ }^{48}$. Una vulneración que se manifiesta en aspectos de una relevancia tal como la recentralización de competencias que

41 CASADO CASADO, L., “Las competencias ambientales de las entidades locales: luces y sombras tras la Ley $27 / 2013$, de 27 de diciembre, de racionalización y sostenibilidad de la Administración local”, Revista Aranzadi de Derecho Ambiental, núm. 32 , dedicado a Homenaje a D. Ramón Martín Mateo (III), 2015.

42 En opinión de Vivancos Comes, las competencias impropias serían aquellas que carecen de cobertura jurídica expresa y financiación suficiente ad hoc, por lo que para que subsistan se requiere un informe previo de carácter autonómico concretando la inexistencia de duplicidades, y un informe del interventor garantizando su sostenibilidad financiera. VIVANCOS COMES, M., "Reflexiones apresuradas sobre la reforma local en ciernes”, Corts. Anuario de Derecho Parlamentario, núm. 27, 2013, pág. 237. Ahora bien, la utilización del adjetivo "propio" por la LRSAL para designar competencias municipales, ha sido criticado por la doctrina al considerar que si el propio art. 7.1 LRBRL lo utiliza para referirse a la titularidad, propia o ajena, de una competencia, no es técnicamente correcto que la misma ley utilice el mismo adjetivo para un fin distinto como es diferenciar entre competencias incondicionadas (las competencias propias) y las condicionadas en su ejercicio (las competencias distintas de las propias). VELASCO CABALLERO, F., "El nuevo régimen local general y su aplicación diferenciada en las distintas comunidades autónomas”, Revista catalana de dret públic (RCDP), núm. 48, 2014, pág. 5. Y, es que "el objetivo fundamental de la ley es: todo aquello que en los municipios no sean servicios obligatorios serán competencias impropias". ZAFRA VÍCTOR, M., "La reordenación de las competencias municipales, entre la eficacia y la democracia”, en FORCADELL I ESTELLER, X., SABATÉ I VIDAL, J. M., (coords.), op. cit., pág. 48.

43 Vid. per totum, "Medidas de redimensionamiento del sector público instrumental local antes y después de la Ley $27 / 2013$, de 27 de diciembre, de racionalización y sostenibilidad de la Administración Local, Revista General de Derecho Administrativo (RGDA), núm. 36, mayo 2014; FLORES DOMÍNGUEZ, L. E., “La reordenación del sector público local”, QDL, núm. extraordinario, op. cit., pág. 206, de un lado. $\mathrm{Y}$, de otro, el empowerment de las diputaciones provinciales a las que se atribuyen mayores competencias en el control y gestión municipal. Ahora bien, "si bien parece que refuerza a la institución provincial, también es cierto que mediante una lectura atenta y un atinado desarrollo legislativo de la misma podría abrir la puerta a algunas propuestas, que permitirían un avance en una estructuración de segundo nivel de Gobierno local alternativa al régimen provincial vigentes por parte de las comunidades autónomas". SABATÉ I VIDAL, J. M., "El impacto de la Ley 27/2013, de 27 de diciembre, de racionalización y sostenibilidad de la Administración local, en el régimen de las diputaciones provinciales y entes equivalentes”, en FONT LLOVET, T.; GALÁN GALÁN, A., Anuario del Gobierno Local 2013..., op. cit., pág. 133. Al respecto, asimismo, vid. GARCÍA RUBIO, F., “Las entidades supramunicipales en el Gobierno local español. Reflexiones tras la reforma de la sostenibilidad”, QDL, núm. extraordinario, op. cit., 2014, págs. 162-198.

44 Vid. in totum, FUEYO BROS, M., "Fortalecimiento de la figura del interventor. Función interventora y control interno: el control esvanecido”, en CARRILLO DONAIRE, J. A., NAVARRO RODRÍGUEZ, P., op. cit., pág. 383-421; CANTERO MARTíNEZ, J., "Reforma local y función pública. El nuevo régimen de los funcionarios locales con habilitación de carácter nacional”, en QUINTANA LÓPEZ, T., et alter, op. cit., págs. 645-713; LÓPEZ GARCÍA MARTÍNEZ, A., “El fortalecimiento de la intervención local y la garantía de un mejor control interno económico-financiero y presupuestario en RODRÍGUEZ-ARANA MUÑOZ, J., SARMIENTO ACOSTA, M. J., (dirs.), op. cit., págs. $237-274$

45 Se limita la iniciativa económica local en lo referente a autorizaciones administrativas y monopolios como mercados y Ionjas, que en determinados casos deberán suprimirse. En definitiva, "la LRSAL, viene a concretar que debe entenderse por oportunidad de conveniencia para el establecimiento de actividades económicas, no pudiéndose desligar esas circunstancias por oportunidad de conveniencia en las leyes económicas, esto es las circunstancias del momento." GARCÍA RUBIO, F., "La iniciativa económica local tras la ley 27/2013, de 27 de diciembre, de racionalización y sostenibilidad de la administración local”, REALA, núm. 3 , enero-junio, 2015, pág. 25.

46 De entre estas líneas normativas, nos detendremos con posterioridad en la tercera, en relación al control económico-financiero y en la última. La Ley pretende esencialmente mejorar la eficiencia y reducir el gasto público de las EELL, resultando ser la medida estrella para alcanzar dichos objetivos el refuerzo del papel de la función interventora en las EELL, según el preámbulo, “en la línea de garantizar la profesionalidad y la eficacia de las funciones de control interno" del interventor local y "asimismo, con el objeto de reforzar su independencia con respecto a las EELL en las que prestan sus servicios los FHN, corresponde al Estado su selección, formación y habilitación así como la potestad sancionadora en los casos de las infracciones más graves".

47 Vid. las motivaciones de las enmiendas al Proyecto de LRSAL (PLRSAL), Boletín Oficial de las Cortes Generales (BOCG), X Legislatura, Congreso de los Diputados (CD), núm. 58-2, de 30 de octubre de 2013, págs. 1-328.

48 SALAZAR BENÍTEZ, O., op. cit., pág. 390. Así mismo, vid. VIVANCOS COMES, M., op. cit., pág. 235. 
son "usurpadas" a sus legítimos titulares — los municipios—o, precisamente, en la "comisarización" de los FHN, con el fin de convertirlos en un mero apéndice del MHAP, tema sobre el que ahondaremos a lo largo de las siguientes páginas.

Como pone de manifiesto la Izquierda Plural en su enmienda a la totalidad del PLRSAL,"esta reforma elimina el poder de lo más cercano, aleja a la ciudadanía de la gestión de lo público, y fortalece la deriva autoritaria, en un momento en el que la ciudadanía exige más participación, más democracia y más transparencia. El gobierno responde con más tutelaje, menos democracia y menos participación en los asuntos públicos"49. En la misma línea, afirmaba la Diputada Olaia Fernández Dávila, del Grupo Parlamentario Mixto, en su enmienda a la totalidad al PLRSAL, que "la obsesión por el cumplimiento del déficit no está alcanzándose con un sector público más eficaz, sino más ausente, que reduce su actuación en servicios y actividades de interés público en momentos de necesidades crecientes para una amplia mayoría de ciudadanos" ${ }^{50}$. Tras el discurso de querer acabar con la falta de confianza en las instituciones, de regenerar los valores en la Administración pública y acercar a ella al ciudadano, se encuentra una Ley que no consigue ser coherente con sus propósitos en su contenido ${ }^{51}$ y que corre el riesgo de propugnar una "reforma ficticia", en palabras del Prof. Sabino Cassese ${ }^{52}$.

En este sentido, se afirma que con esta reforma se va a sufrir un retroceso hacia la Administración pública del siglo XIX, a la Ilamada “España del ochocientos" 53 , sobre la base de la "resurrección" de la vinculación triangular Estado-municipio-interventor/secretario, en el que el gobernador civil en su papel de autoridad provincial era una pieza esencial del sistema como agente estatal de controla la actividad municipal. En aquella época era posible que las mejoras de gestión, modernización y desarrollo local provinieran de la injerencia y no de la autonomía. Está claro que ese criterio es totalmente anacrónico y no puede compartirse en la actualidad, cuando las mejores propuestas vienen en su mayoría impulsadas desde los municipios, que constituyen los verdaderos laboratorios de innovación democrática ${ }^{54}$. Así, Alexis de Tocqueville afirmaba que "las instituciones municipales para la libertad lo que las escuelas primarias para la ciencia: la ponen al alcance del pueblo, le hacen gozar de su uso pacífico y le acostumbran a servirse de ella" 55 . Y es que "la força del poder local prové del fet que és el poder amb més capacitat d'innovació i de recerca de noves solucions. I el mètode per assolir-ho és l'aplicació d'un altre dels principis poc arrelats en la nostra cultura jurídica, com és el "principi d'experimentació"” 56.

Atendiendo a la dinámica social, con el añadido de la deteriorada legitimidad democrática de los gobiernos locales ${ }^{57}$, resulta evidente que los ciudadanos, cada vez más conscientes y críticos, reclaman la aplicación de un conjunto de valores éticos que no puede tener lugar en la Administración tradicional ${ }^{58}$. Así, "este nuevo paradigma relacional en cuyo centro se debe situar el individuo requiere de un verdadero replanteamiento de la arquitectura de los gobiernos locales" 59 . Las reformas deben impulsar la evolución del sector público de forma paralela a la evolución social, y no a la inversa.

49 Diputados Chesús Yuste Cabello y José Luis Centella Gómez, portavoces, Grupo Parlamentario La Izquierda Plural, BOCG, X Legislatura, CD, op. cit., pág. 12.

50 Diputada Ma. Olaia Fernández Dávila, Grupo Parlamentario Mixto, BOCG, X Legislatura, CD, op. cit., pág. 12.

51 "La LRSAL es una muestra más de la involución que está representando, bajo el pretexto de la crisis económica, 'la progresiva limitación de las condiciones formales y materiales que habían conformado hasta ahora a las democracias pluralistas y el debilitamiento de la normatividad de la Constitución””. SALAZAR BENÍTEZ, O., “La autonomía local devaluada:...”, op. cit., pág. 393.

52 "Dado que las políticas de reforma o de modernización administrativa ya se han generalizado y ningún Gobierno quiere rehuirlas, no pocos Gobiernos cambian todo para que nada cambie, estimulando transformaciones ficticias." CASSESE, S., Derecho Administrativo: historia y futuro, INAP, Global Law Press, Madrid, 2014, pág. 370.

53 TOSCAS SANTAMANS, E., AYALA DOMÈNECH, F., "De las relaciones centro-periferia en el Estado liberal. Gobernadores civiles, ayuntamientos y secretarios municipales en la España del Ochocientos”, El Consultor de los Ayuntamientos, núm.5, año 2010, pág.766.

54 A pesar de que "su legitimidad democrática les capacita para decidir, priorizando determinadas políticas y prestaciones frente a otras, en función de sus objetivos orientados al interés general”. GIFREU I FONT, J., "Presentació” de ZAFRA VÍCTOR, M., "Reordenación de las competencias municipales, entre la eficacia y la democracia”, en FORCADELL I ESTELLER, F. X., SABATÉ VIDAL, J., M. op. cit., 2013 , pág. 44.

55 TOCQUEVILLE, A. de, La democracia en América, vol. I, pág. 62.

56 BALLBÉ MALLOL, M., FUENTES i GASÓ, J. R., "Nous principis i capacitats competencials", en II Congrés de Municipis de Catalunya. Una aposta de futur, Barcelona, 2003, pág. 408.

57 Para la reforma local, "otros criterios de valoración que igualmente son oportunos y, entre ellos, especialmente, el de mejora de la calidad democrática”. FONT LLOVET, T., GALÁN GALÁN, A., “Gobierno local y reorganización: ¿la reforma vendrá de Europa?”, en FONT LLOVET, T., GALÁN GALÁN, A., Anuario de Gobierno Local 2011. Gobierno Local: ¿crisis o renovación?, Fundación Democracia y Gobierno local, Madrid, abril 2012, pág. 12.

58 ALDEGUER CERDÁ, B., "Ética pública y gobierno local en un contexto de crisis económica”, Barataria, Revista Castellano-Manchega de Ciencias Sociales, núm. 15, 2013, pág. 30.

59 FUENTES I GASÓ, J. R., "Gobiernos locales, retos de futuro", Revista Democracia y Gobierno Local (RDGL), núm. 29, segundo trimestre, 2015, pág. 8. 


\section{LA APUESTA POR LA REGENERACIÓN DEMOCRÁTICA: UNA NUEVA CONCEPCIÓN DEL FUNCIONARIO LOCAL CON HABILITACIÓN NACIONAL ${ }^{60}$}

Pese al amplio alcance de la LRSAL —visto a grandes rasgos en el apartado anterior — vamos a centrarnos en las modificaciones relativas al régimen jurídico de los FHN; pues por sus funciones, características e importancia merecen una especial atención en relación al cumplimiento efectivo de los objetivos con que se justifica la propia Ley ${ }^{61}$. Y, por encima de todo, se convierten en los artífices de una nueva función de de la Administración local que hemos denominado de "regeneración democrática". Así, "las energías empleadas por estas personas [FHN] en ese desempeño han procurado, al menos, que el deterioro de nuestras administraciones locales, que podía haber sido mucho mayor del que ha sido en términos de falta de eficacia y eficiencia, falta de buen gobierno y buena administración de los fondos públicos, corrupción, etc., no lo haya sido en mayor grado" ${ }^{2}$.

De tal modo que en cuanto al régimen jurídico, la dirección tomada por la reforma que nos ocupa en principio parecería la adecuada, al pretender reformar el deficiente sistema interno de control y fiscalización jurídico, pero en especial económico; pues aunque las medidas propuestas son del todo perfectibles, al menos reconoce se la necesidad de dotar de mayor independencia a estos colectivos de FHN.

\section{III.1. El régimen jurídico preexistente a la LRSAL}

Sin ánimo de exhaustividad y más bien de forma sucinta, vamos a analizar los elementos más relevantes del régimen jurídico de los FHN, en el marco vigente hasta la aprobación de la LRSAL al efecto de comprender cómo incide de forma decisiva dicha norma en la regulación de este colectivo de funcionarios locales sui generis, con más de doscientos años al servicio de la legalidad y la integridad públicas ${ }^{63}$. $Y$ es que "el secretario municipal ha sido históricamente en España —al igual que en Italia — una figura importante de la administración local, pero ha sufrido en las dos últimas décadas un notable debilitamiento, lo que incide negativamente no sólo en el colectivo funcionarial y en la Administración, sino también en la ciudadanía" ${ }^{64}$.

La denominación legal de esta "escala funcionarial" hasta la aprobación de la LRSAL era la de "funcionarios de administración local con habilitación de carácter 'estatal”". Inicialmente, la Ley Municipal de 31 de octubre de 1935 de la II República los denominó Cuerpos Nacionales de Administración Local ${ }^{65}$. Sin embargo, a partir de la LRBRL, y hasta la aprobación de la Ley 7/2007, de 12 de abril, del Estatuto Básico del Empleado Público (EBEP), se les conoció como "funcionarios de administración local con habilitación de carácter nacional"; denominación que la LRSAL recupera. Ahora bien, las referencias a los FHN se hallan contenidas en multitud de normas, más allá de las citadas. Unas de ámbito general ${ }^{66}$, como los anteriores, y otras relativas al estatuto jurídico del propio colectivo ${ }^{67}$.

60 El número de efectivos del personal al servicio de los EELL ascendía a 577.164, el 22,68\% de los 2.544 .804 efectivos del conjunto de las Administraciones públicas, ligeramente por encima del 21, 08\% que corresponde a la Administración General del Estado (AGE) y muy por debajo del 50.46\% que corresponde a las CCAA. De esta cifra, tan sólo 5.647, el 0.98\% del conjunto del personal local, pertenece a los FHN. MHAP, Boletín Estadístico del Personal al servicio de las Administraciones Públicas, Registro Central de Personal, enero, 2015, http:// www.seap.minhap.gob.es/dms/es/web/publicaciones/centro_de_publicaciones_de_la_sgt/Periodicas/parrafo/Boletin_Estadis_Personal/BEP_ ENERO-2105.PDF.

61 Cabe poner de manifiesto que el MHAP ha redactado un borrador de Real Decreto por el que se regula el régimen jurídico de los funcionarios de administración local con habilitación de carácter nacional (versión 9/12/2014) http://www.minhap.gob.es/Documentacion/ Publico/NormativaDoctrina/Proyectos/BORRADOR\%20REGLAMENTO\%20 HCN\%20\%28remitido\%20audiencia\%20interesado\%2026\%201\%20 15\%29.pdf. A este documento el CSITAL de Cataluña presentó alegaciones el 12/2/2015, http://www.csital.org/sites/default/files/20150213_ Al\%C2\%Blegacions_Ministeri_Hisenda_presentades.pdf.

62 ÁVILA CANO, E., op. cit., pág. 302.

63 Vid. in totum, AGIRREAZKUENAGA ZIGORRAGA, I., Origen de los funcionarios locales de habilitación estatal: los cuerpos nacionales, Instituto Vasco de Administración Pública, Oñati, 1996; MARTíNEZ MARÍN, A. Funcionarios locales con habilitación. Pasado, presente y futuro, Tecnos, Madrid, 1999; ORDUÑA REBOLLO, E., "Historia de una profesión al servicio de la ciudadanía: secretarios, interventores y tesoreros de la administración local española”, en ORDUÑA REBOLLO, E., MERINO ESTRADA, V. (coord..), op. cit., pág. $13-296$.

64 TOSCAS SANTAMANS, E., "Las nuevas normas sobre los secretarios de los ayuntamientos en España: un ejemplo de desregulación de la función pública”, Scripta Nova, Revista Electrónica de Geografía y Ciencias Sociales, vol. XII, núm. 270 (34), 2008 , pág. 1.

65 Creados por el Estatuto Municipal de Calvo Sotelo de 1924 que es "la verdadera norma fundacional del empleo público local", puesto que supone "el primer intento de profesionalizar una parte importante de la burocracia local por la vía de reglamentar su acceso en una norma formal y de garantizar cierta independencia a puestos críticos en el funcionamiento municipal como los secretarios y los interventores". CUENCA CERVERA, J. J., La difícil institucionalización de la democracia local en España: la pervivencia del legado histórico, IX Congreso de la Asociación Española de Ciencia Política y de la Administración (AECPA), Málaga, septiembre, 2009, pág. 7.

66 Así destacamos, el Real Decreto Legislativo (RDLeg.) 2/2004, de 5 de marzo, por el que se aprueba el texto refundido de la Ley Reguladora de las Haciendas Locales (TRLRHL); RDLeg. 3/2011, de 14 de noviembre, por el que se aprueba el Texto Refundido de la Ley de Contratos del Sector Público (TRLCSP); Ley 33/2003, de 3 de noviembre, del Patrimonio de las Administraciones Públicas (LPAP) y la Ley Orgánica 5/1985, de 19 de junio, del Régimen Electoral General (LOREG).

67 Real Decreto 1174/1987, de 18 de septiembre, por el que se regula el régimen jurídico de los funcionarios de Administración Local con habilitación de carácter nacional (RD 1174/1987); RD 834/2003, de 27 de junio, por el que se modifica la normativa reguladora de los sistemas de selección y provisión de los puestos de trabajo reservados a funcionarios de Administración local con habilitación de carácter nacional en adelante (RD 834/2003); RD 522/2005, de 13 de mayo, por el que se modifican los requisitos para la integración de los funcionarios de Administración local con habilitación de carácter nacional pertenecientes a la Subescala de Secretaría-Intervención (RD 522/2005). 
En lo relativo a su estructuración, el colectivo se organiza como una "escala" diferenciada de las de “administración general” y “administración especial”, y se divide en tres subescalas: "secretaría”; “intervencióntesorería"; y "secretaría-intervención” -a su vez, las dos primeras pueden ser de categoría de "entrada” o "superior" 68 .

Por lo que respecta a la selección, nombramiento y toma de posesión, hasta la aprobación de la LRSAL las Comunidades Autónomas (CCAA) "gozaban de un protagonismo absorbente" ${ }^{69}$, de acuerdo con la normativa estatal. Como veremos, la LRSAL supone "reestatalización” o "recentralización” del conjunto del régimen jurídico de los FHN. Así, en cuanto a la selección, los aspirantes a un empleo público de FHN deben demostrar su mérito y capacidad, ex art. 103.1 CE. La capacidad se aprecia a través de la oposición, un sistema selectivo de pruebas de conocimientos tanto teóricos como prácticos al que se somete a estos candidatos ${ }^{70}$. El mérito se identifica en la fase de concurso, y consiste en la comprobación y calificación de las características y actividades de toda índole del candidato, reflejadas en su curriculum vitae ${ }^{71}$.

La Ley 31/1991, de 30 de diciembre, de Presupuestos Generales del Estado para 1992 la que inició la provisión mediante libre designación para determinados puestos reservados a los FHN ${ }^{72}$. El EBEP permitía la libre designación también para el secretario de ayuntamientos de grandes poblaciones ${ }^{73}$. Una forma de provisión que no permite la valoración de los principios de mérito y capacidad ${ }^{74}$ — muy a menudo también incumple los de publicidad y concurrencia- y que supone "una involución o tendencia al "regreso" al siglo XIX75 y el peligro de que "el controlado es el que libremente designa y cesa libremente a su propio controlador" 76 . Lo que redunda en la finalidad perversa de mecanismos incentivadores de la permisividad, que acaban generando los múltiples casos de corrupción con que convivimos a diario. Pues aunque se diseña la libre designación como algo excepcional cuyo uso debe restringirse a puestos de trabajo de especial responsabilidad y confianza, su amplia definición deja al arbitrio de cada Administración determinar en qué puestos concurren dichas circunstancias, propiciando un uso abusivo de esta posibilidad77.

En cuanto a la provisión, el sistema normal es el concurso ordinario, cuyo ámbito territorial era, hasta esta reforma, el de la Comunidad Autónoma (CA) que regulaba las bases comunes y el porcentaje de puntuación que correspondía a cada uno de los méritos valorables ${ }^{78}$. El MHAP, de forma supletoria al concurso ordinario, convocaba el concurso unitario anual de ámbito territorial estatal, en función de los méritos generales y los de valoración autonómica79.

68 Arts. 20 y 22.2 del RD 1174/1987. Los aspirantes de las pruebas selectivas deberán estar en posesión de los título académico superior de licenciado —o de sus equivalentes de grado derivados del Espacio Europeo de Educación Superior-: secretaría —-derecho, ciencias políticas y de la Administración, sociología—; intervención-tesorería —-derecho, administración y dirección de empresas, economía, ciencias actuariales y financieras - y secretaria-intervención — cualquiera de los citados— (art. 22.1 del RD 1174/1987).

69 BASSOLS COMA, M., "La racionalización de la administración local en el marco de la sostenibilidad, financiera, panorama general”, QDL, núm. 34 extraordinario, febrero 2014, pág. 43.

70 ARIAS DÍAZ, I., op. cit., pág. 110.

71 De forma excepcional, los municipios de gran población, las diputaciones provinciales, los cabildos y los consejos insulares pueden cubrir por el sistema de libre designación, entre FHN de la subescala y categoría correspondientes, los puestos a ellos reservados que se determinasen en las relación de puestos de trabajo. SERRANO PASCUAL, A., "El régimen jurídico de los funcionarios con habilitación de carácter estatal”, El Consultor de los Ayuntamientos y los Juzgados, núm. 24, 2008-2009, pág. 20. Así mismo, en relación al concepto de “mérito”, vid. GARCÍA GARCÍA, M., J., “Los principios constitucionales de igualdad, mérito y capacidad: su plasmación en el Estatuto del Empleado Público”, Revista Jurídica de Castilla León, núm. 15, mayo 2008, págs. 132-135.

72 Disposición adicional (DA) 8. No obstante, después se incluyó en la Ley 10/1993, de 21 de abril, que modificaba el régimen de puestos de trabajo reservados a los FHN, para evitar la tacha de inconstitucionalidad para una norma presupuestaria que se ocupaba de un tema extrapresupuestario. SERRANO PASCUAL, A., op. cit., pág. 12.

73 DA 2.52 2) del EBEP. Ley 57/2003, de 16 de diciembre, de Medidas para la Modernización del Gobierno Local que añade el título X "Régimen de organización de los municipios de gran población”, a la LRBRL (art. 129). En estos municipios, el puesto del “secretario" ha desaparecido, aunque deben existir puestos de trabajo desempeñados únicamente por éstos, como el "secretario general del pleno" o el titular del "órgano de apoyo al concejal secretario de la junta de gobierno local”, teniendo en cuenta que sus competencias se reducen al ámbito concreto de dichos órganos, que tanto pueden hallarse en los ayuntamientos como en las diputaciones, mancomunidades, consorcios locales y otros organismos autónomos dependientes de las EELL. ÁVILA CANO, E., "El papel de los secretarios, interventores y tesoreros en los Ayuntamientos", http://www.theeconomyjournal.com, en fecha 13/03/2013.

74 Vid. COCCIOLO, E., REQUEJO GARCÍA, J., “L’ocupació pública a les administracions locals: la difícil relació entre principis i praxis”, en MOLES PLAZA, R. J., y COCCIOLO, E. E., op. cit., pág. 51 y ss.

75 TOSCAS SANTAMANS, E., op. cit., pág. 6.

76 ÁVILA CANO, E., "El control de secretarios e interventores municipales", en AAVV., Urbanismo y democracia. Alternativas para evitar la corrupción, Fundación Alternativas, Madrid, 2007, pág. 122

77 ARIAS DÍAZ, I., op. cit., pág. 115.

78 DA 2.4 del EBEP. A saber: generales — grado personal, trabajo desarrollado, cursos de formación y perfeccionamiento superados, antigüedad-; los correspondientes al conocimiento de las especialidades de la organización territorial, la lengua oficial de cada Comunidad junto con su derecho propio y los específicos, adecuados a las características del puesto (DA 2.5 EBEP).

79 DA 2.5 EBEP. 
$\mathrm{Y}$, por lo que respecta a la delimitación de funciones reservadas a los FHN, fuertemente vinculadas al control de la legalidad, en vigor antes de la LRSAL, debemos acudir tanto al RD 1174/1987 como al EBEP ${ }^{80}$. El "secretario" — "que desde la LRBRL había perdido gran parte de sus antiguas atribuciones de jefe administrativo" 81 ejerce la función de "fe pública" y, en consecuencia, da fe del contenido exacto de los "acuerdos" del pleno, de la junta de gobierno, de las comisiones informativas y de los otros órganos que puedan constituirse; así como de los "decretos" o "resoluciones" dictados por el alcalde y los concejales delegados y, en general de los actos jurídicos documentados de la entidad local ${ }^{82}$. Asimismo, ejerce la función de "asesoramiento legal preceptivo" cuando lo ordene el alcalde, lo solicite un tercio de los concejales por mayoría absoluta del pleno o así lo establezca una norma ${ }^{83}$.

En este sentido, el ideal de que el secretario de Administración local era el garante de legalidad de las actuaciones municipales y, por ende, de la comunidad local en una España del pasado, no se corresponde con una normativa confusa, modificada en multitud de ocasiones y manifiestamente mejorable, como la vigente. Con cada reforma normativa se ha ido reduciendo el ámbito competencial de este empleado público, situándolo en una posición muy complicada y no exenta de tensiones al tener que cuestionar a menudo la legalidad de los actos desde la "propia" Administración"

El "interventor" ejerce la "función de control y fiscalización interna de la gestión económico-financiera y presupuestaria" ${ }^{85}$ y es el "responsable de la adecuación de la gestión económica de cada Ayuntamiento o Diputación a los requisitos que establece la legislación de haciendas locales" ${ }^{86}$. Así, fiscaliza todos los actos que den lugar a un reconocimiento de derechos u obligaciones de contenido económico. Informa —-mediante una declaración preceptiva de juicio, de carácter independiente, interno y preventivo — sobre la legalidad de cada ingreso, gasto o pago, siendo responsable personalmente si no formula reparo en los casos de ilegalidad. Ejerce el control financiero a posteriori, una suerte de auditoría o control de eficacia que realizan mediante la comprobación periódica del grado de cumplimiento de los objetivos. Analiza el coste de funcionamiento y rendimiento de los servicios o inversiones de la entidad local ${ }^{87}$.

Y por último, el “tesorero" 88 es el responsable del manejo y custodia de los caudales públicos y de los servicios recaudatorios ${ }^{89}$.

80 El art. 1 del RD 1174/1987 dispone que la función de "secretaría” comprende la fe pública y el asesoramiento legal preceptivo, desarrollando lo que implica cada una de estas funciones en los arts. 2 y 3. Asimismo, este precepto establece que el control y la fiscalización interna de la gestión económico-financiera y presupuestaria, y la contabilidad, tesorería y recaudación son funciones públicas necesarias en todas las EELL (arts. 4, 5 y 6). De igual modo, en la ya derogada DA 2 EBEP.

81 TOSCAS SANTAMANS, E., op. cit. pág. 1.

82 Comprende, entre otras tareas, “la preparación de los asuntos que hayan de ser sometidos al Pleno o a cualquier otro órgano de la Corporación, custodia de los expedientes incluidos en el orden del día de sus sesiones, levantar acta de ésta y someterla a la aprobación de sus miembros, certificar las resoluciones y acuerdos de los órganos de la Corporación, llevar y custodiar el registro de intereses de los miembros de la Corporación y el Inventario de los bienes de la Entidad." MARTINEZ MARíN, A., "La reforma de 2003 de los funcionarios locales con habilitación nacional, REALA, núm. 291, 2003, pág. 670.

83 Comprende "la emisión de informes preceptivos para la adopción de los acuerdos que lo tengan establecidos así como acompañar al Presidente o miembros de la Corporación en los actos de firma de escrituras o acompañarles en sus visitas a otras autoridades o reuniones en que éstos se lo demandaren a efectos de proporcionarles el concreto asesoramiento legal.” Ibidem, pág. 670.

84 "Se evidencia claramente el proceso de pérdida de protagonismo y competencias de los secretarios municipales". VERA TORRECILLAS, R, “Las funciones reservadas y el Estatuto Básico del Empleado Público: algunas consideraciones sobre la reforma de los Funcionarios de Habilitación Estatal”, El Consultor de los Ayuntamientos y de los Juzgados, núm. 9, 2009 , pág. 9.

85 En los municipios con menos de 5.000 habitantes, son los “secretarios-interventores" quienes realizan ambas funciones. Nótese que el MHAP ha redactado un Proyecto de RD por el que se regula el régimen jurídico del control interno de las entidades del sector público, http://www.csital.org/sites/default/files/RD\%20Cl\%20EELL\%20Versi\%C3\%B3n\%2023-03-2015.pdf (versión 23/3/2015), al que el CSITAL de Cataluña presentó alegaciones el 15/4/2015, http://www.csital.org/sites/default/files/al_legacions_regim_control_intern.pdf. Vid. in totum VIÑAS BOSQUET, J., P., “Fundamentos, contenido y derecho comparado del control interno en las entidades locales, REALA, núm. 296-297, 20042005, págs. 425-472.

86 SÁNCHEZ BLANCO, A., “La función pública de los Secretarios e Interventores de la Administración local”, REALA, núm. 291, 2003, pág. 1026.

87 Además, entre otras medidas, se dispone un breve plazo para la rendición de cuentas a mancomunidades y entidades locales menores bajo amenaza de desaparición en caso contrario. Se establece incluso la posibilidad de intervenir el municipio esgrimiendo razones de estabilidad presupuestaria. Y, a partir de ahora, será el Gobierno quien fijará los procedimiento de control, los criterios de actuación, la metodología de aplicación y los derechos y deberes en el desarrollo de las funciones públicas necesarias en todas las corporaciones locales.

88 No obstante, en los municipios con menos de 20.000 habitantes esta función es llevada a cabo por algún funcionario del ayuntamiento o por un concejal.

89 Cabe destacar algunas funciones más de los FHN. El secretario asiste a todas las sesiones ordinarias y extraordinarias (art. 46.2.C) LRBRL); forma parte de la junta electoral de zona como delegado, siendo estrictamente dependiente de ésta (art. 114 LOREG); notifica a los miembros del pleno extraordinario en caso de ser solicitado por los concejales y no convocado por el presidente, pues quedaría automáticamente convocado (art. 46.2.a) LRBRL); debe de remitir a las Administraciones del Estado y de las CCAA copia o extracto comprensivo de los actos y acuerdos (art. 56.1 LRBRL). se dirige al represente legal de la formación política que presentó la candidatura correspondiente en caso de abandono o expulsión de algunos de sus miembros (art. 73.3 LRBRL) y notifica la comunicación de actuaciones urbanísticas que afecten a bienes de titularidad pública (art. 189.3 LPAP). El interventor ejerce la función interventora en sus diversas modalidades y formula reparos en caso de desacuerdo con el fondo o la forma de los actos (art. 214 y Ss. TRLRHL). Y ambos forman parte de todas las mesas de contratación (art. 320.3 LCSP) y de las juntas de contratación (DA 2.4); emiten sendos informes previos respecto 
La complejidad técnica y jurídica de semejantes funciones justifica, como afirma Vera Torrecillas, la necesidad de una preparación específica que viene dada por la propia naturaleza e importancia de las funciones de este colectivo para el buen funcionamiento de las administraciones locales en cada territorio ${ }^{90}$. Una funciones de relevancia constitucional en tanto que se dirigen a satisfacer los principios legalidad, de eficiencia y eficacia en la actuación administrativa y, sin duda, a prevenir la corrupción que ésta puede acarrear.

\section{III.2. ¿Cómo incide la reforma local en el rol del funcionario local con habilitación nacional? ${ }^{91}$}

La nueva regulación, que pretende recuperar el régimen jurídico previo al EBEP, con el consiguiente retorno de muchas de las competencias sobre los habilitados nacionales al Estado, contiene aspectos positivos y otros más controvertidos con la reincorporación del régimen jurídico de los FHN —antes previsto en el derogado art. 92 en la LRBRL - a través de un nuevo art. 92 bis ${ }^{92}$. Entre los controvertidos, destaca que la competencia para la convocatoria, selección y formación de estos funcionarios, así como la creación, provisión, clasificación y supresión de los puestos reservados a ellos, y el régimen disciplinario que les sea aplicable, hasta el momento en manos de las CCAA, retornan al Estado ${ }^{93}$.

En la provisión, la "recentralización” igualmente se hace bien patente. Existirán dos concursos anuales: el concurso ordinario de ámbito estatal —en el que pasan a ser predominantes los méritos estatales ${ }^{94}$ — y cuyas bases serán aprobadas por las EELL con puestos vacantes, de acuerdo con el modelo de convocatoria y bases comunes que aprobará la Administración General del Estado (AGE); y el concurso unitario, de ámbito igualmente estatal, y que efectuará el MHAP de forma supletoria respecto de los puestos vacantes reservados a estos funcionarios ${ }^{95}$. A esto debe añadirse la desaparición del conocimiento de la lengua propia de las CCAA y el conocimiento de su derecho propio como elementos integrantes de los méritos en dichos concursos; cosa que ha sido duramente criticada; puesto que suponen una merma de competencias en el ejercicio de sus funciones ${ }^{96}$.

El nuevo artículo 92 LRBRL recuerda las funciones públicas reservadas a funcionarios de carrera, a que impliquen la participación directa o indirecta en el ejercicio de las potestades públicas o en la salvaguardia de los intereses generales, las que impliquen ejercicio de autoridad, y en general, aquellas que se reserven a los funcionarios para la mejor garantía de la objetividad, imparcialidad e independencia en el ejercicio de la función, entre las cuáles, sin duda, deben contarse las reservadas a los FHN ${ }^{97}$. Además, cabe destacar la introducción de un nuevo art. 32 bis LRBRL que incluye los FHN entre funcionarios que pueden desempeñar funciones directivas ${ }^{98}$ en diputaciones provinciales y consejos insulares, sin hacer referencia al ámbito municipal ${ }^{99}$.

\section{III.3. Las funciones públicas necesarias como fundamento de la función de regeneración democrática local ${ }^{100}$}

En nuestro sistema local, a diferencia del segretario italiano — como veremos a continuación—, no hay una atribución específica de prevención de la corrupción ni a los FHN, ni a funcionario alguno. Ahora bien, de forma implícita son las funciones públicas necesarias que tradicionalmente nuestro ordenamiento atribuye a los FHN las que cumplen este cometido fundamental en un estado de Derecho fundamentado en el principio democrático.

del pliego de cláusulas administrativas particulares (DA2.7) y sobre la justificación de la causa de urgencia en los casos en que se aplique el procedimiento negociado de urgencia. (DA2.9) y redactan un informe previo de legalidad y otro informe previo cuando afecte a derechos y obligaciones de contenido económico cuando se ejerza la iniciativa popular (art. 70 bis.2 LRBRL).

90 VERA TORRECILLAS, R,, op. cit., pág. 9.

91 http://www.famp.es/famp/programas/seminarios cursos jornadas/14 AdmonLoc/informe.pdf.

92 Por ejemplo, la restricción de nombramientos provisionales y la obligación de permanencia de dos años en el puesto adjudicado en el próximo concurso conllevan consecuencias tan indeseadas como la dificultad para la cobertura de puestos de entrada y superior en localidades de hasta 20.000 habitantes. VIVANCOS COMES, M., op. cit. pág. 245.

93 Competencias que hasta ese momento la DA 2 del EBEP otorgaba a las CCAA (art. 1.25 LRSAL).

94 Exigiéndose un mínimo del $85 \%$, frente a los autonómicos y los locales, para los que se prevé un $10 \%$ y un $5 \%$ respectivamente.

95 Las CCAA también podrán convocar puestos vacantes que no hayan sido convocados por las EELL mediante los concursos ordinarios, de forma supletoria.

96 La provisión de puestos de trabajo mediante la libre designación se mantiene para los municipios incluidos en el ámbito subjetivo definido en los artículos 11 y 135 del TRLRHL, así como las diputaciones provinciales, cabildos y consejos insulares, Ceuta y Melilla.

97 El art. 92 bis 1 b) in fine LRBRL demás incluye una cláusula final abierta: "No obstante, en los municipios de gran población se tendrá en cuenta lo dispuesto en el Título X de la presente Ley y en los municipios de Madrid y de Barcelona la regulación contenida en las Ley 22/2006, de 4 de julio, de Capitalidad y de Régimen Especial de Madrid y Ley 1/2006, de 13 de marzo, por la que se regula el Régimen Especial del municipio de Barcelona respectivamente."

98 Exigiéndoles para su ingreso el título de doctor, licenciado, ingeniero, arquitecto o equivalente (art. 1.12 LRSAL).

99 Según Mellado Ruiz esta medida pretende dotar del máximo de objetividad el nombramiento y el régimen jurídico de estos directivos para fortalecer su legitimidad, aunque es criticable que se permita la libre designación en estos casos al no establecerse lo contrario. MELLADO RUÍZ, L., “Notas críticas sobre el Anteproyecto de Ley para la racionalización y sostenibilidad de la Administración Local. Entre la reforma y la intervención”, Revista CEMCI, núm. 17, 2012, pág. 32.

100 En relación con las funciones reservadas a funcionarios en general, vid. in totum el excelente trabajo de JORDANO FRAGA, J., "Grietas en los ejes del modelo constitucional: las funciones reservadas a los funcionarios", Revista Española de Derecho Administrativo (REDA), Octubre-Diciembre 2015, págs. 151-186.

REALA, n 4, julio-diciembre 2015, ISSN: 1989-8975 - DOI: http://dx.doi.org/10.24965/reala.voi4.10305 
Unas funciones públicas necesarias que han de ser leídas a la luz de la CE y de los tratados internacionales ${ }^{101}$, de leyes fundamentales para la transformación administrativa ${ }^{102}$ y que con el impulso de la $\operatorname{LRSAL}^{103}$ conllevan el aggiornamento de los principios y valores que han de regir la res publica y que constituyen una verdadera "función de regeneración democrática" de la Administración local conferida a los FHN.

El nuevo art. 92 bis.1 LRBRL ${ }^{104}$ contiene el elenco de funciones públicas necesarias en todos los EELL, cuyo ejercicio se reserva a FHN. Ahora bien, el enunciado que se realiza es muy genérico ${ }^{105}$, para conocer el alcance de dichas funciones es preciso acudir al Real Decreto 1174/1987, de 18 de septiembre ${ }^{106}$, por el que se regula el régimen jurídico de los funcionarios de la Administración local con habilitación de carácter nacional ${ }^{107}$ :

a) La función de secretaría, comprensiva de la fe pública y el asesoramiento legal preceptivo ${ }^{108}$.

- La fe pública comprende la preparación de los asuntos que han de ser sometidos a la aprobación del pleno o de cualquier otro órgano, la custodia de los expedientes incluidos en el orden del día de sus sesiones, levantar acta de éstas y someterlas a la aprobación de sus miembros, certificar los acuerdos y resoluciones adoptados, llevar y custodiar el registro de intereses de los miembros de la corporación y el Inventario de bienes de la entidad.

- El asesoramiento legal preventivo comprende la emisión de informes preceptivos para la adopción de los acuerdos que así lo tengan establecido. Así como acompañar al alcalde o presidente u a otros miembros de la corporación en los actos de firma de escrituras o en sus visitas a otras autoridades o reuniones en que éstos se lo demandaren a efectos de proporcionarles asesoramiento.

b) Las funciones de control y la fiscalización interna de la gestión económico-financiera y presupuestaria, y las de contabilidad, tesorería y recaudación ${ }^{109}$ :

- El control y fiscalización interna de la gestión económico-financiera y presupuestaria comprende la fiscalización de todo acto, documento o expediente que de lugar al reconocimiento de derechos y obligaciones de carácter económico, emitiendo el consiguiente informe o formulando, en su caso, los reparos procedentes, la intervención formal de las órdenes de pago, de los ingresos y la fiscalización de la gestión tributaria; informar los proyectos de presupuestos y de modificación de los créditos de los mismos; la comprobación o auditoría interna de las entidades dependientes, en relación con operaciones no sujetas a intervención previa.

101 Vid. ante las notas 12, 13 y 14.

102 Entre otras, cabe destacar la Ley 19/2013, de 9 de diciembre, de transparencia, acceso a la información pública y buen gobierno, que en su preámbulo dispone que "la transparencia, el acceso a la información pública y las normas de buen gobierno deben ser los ejes fundamentales de toda acción política. Sólo cuando la acción de los responsables públicos se somete a escrutinio, cuando los ciudadanos pueden conocer cómo se toman las decisiones que les afectan, cómo se manejan los fondos públicos o bajo qué criterios actúan nuestras instituciones podremos hablar del inicio de un proceso en el que los poderes públicos comienzan a responder a una sociedad que es crítica, exigente y que demanda participación de los poderes públicos". Ley 40/2015, de 1 de octubre, de régimen jurídico del sector público, que en su art. 3 establece cuáles deben ser los principios de la actuación administrativa: 1. Las Administraciones Públicas sirven con objetividad los intereses generales y actúan de acuerdo con los principios de eficacia, jerarquía, descentralización, desconcentración y coordinación, con sometimiento pleno a la Constitución, a la Ley y al Derecho. Deberán respetar en su actuación y relaciones los siguientes principios: a) Servicio efectivo a los ciudadanos; b) Simplicidad, claridad y proximidad a los ciudadanos; c) Participación, objetividad y transparencia de la actuación administrativa; d) Racionalización y agilidad de los procedimientos administrativos y de las actividades materiales de gestión; e) Buena fe, confianza legítima y lealtad institucional; f) Responsabilidad por la gestión pública; g) Planificación y dirección por objetivos y control de la gestión y evaluación de los resultados de las políticas públicas; h) Eficacia en el cumplimiento de los objetivos fijados; i) Economía, suficiencia y adecuación estricta de los medios a los fines institucionales; j) Eficiencia en la asignación y utilización de los recursos públicos; k) Cooperación, colaboración y coordinación entre las Administraciones Públicas.

103 Sánchez Morón afirma que se deduce del preámbulo que la LRSAL “enlaza la finalidad de garantizar la profesionalidad y eficacia de las funciones de control interno de las entidades locales con la más específica de reforzar la función interventora, para dotar de mayor transparencia y rigor al control económico presupuestario”.SÁNCHEZ MÓRON, M., “El impacto de la reforma de la Administración local en el empleo público", en FONT LLOVET, T., GALÁN GALÁN, A., Anuario del Gobierno Local 2013 ¿Un nuevo gobierno local en España? La reforma de la Administración local en la Ley 27/2013, Institut de Dret Públic, Fundación Democracia y Gobierno local, Barcelona, junio 2014 , pág. 83.

104 Este artículo mantiene el redactado del antiguo art. 92.3 LRBRL derogado en su día por el EBEP.

105 Vid., en este sentido, MARTÍNEZ MARÍN, A., "La reforma 2003 de los funcionarios locales con habilitación estatal”, Revista de Estudios de la Administración Local (REAL), núm 291, enero-abril, 2003, pág. 670-671.

106 Modificado por el Real Decreto 1732/1994, de 29 de julio, sobre provisión de puestos de trabajo reservados a funcionarios con habilitación de carácter nacional y por el Real Decreto 834/2003, de 27 de junio, por el que se modifica la normativa reguladora los sistemas de selección y provisión de los puestos de trabajo reservados a funcionarios de Administración Local con habilitación de carácter nacional.

107 Es preciso referirse al caso catalán que aprobó el Decreto 195/2008, de 7 de octubre, por el cual se regulan determinados aspectos del régimen jurídico del personal funcionario con habilitación de carácter estatal da las entidades locales de Catalunya, en desarrollo del EBEP, y que se debe entender derogado en todo aquello que se oponga al nuevo art. 92 bis LRBRL.

108 Arts. 2 y 3 del RD 1174/1987.

109 Arts. 4, 5 y 6 del RD 1174/1987. 
- La tesorería comprende el manejo y custodia de fondos, valores y efectos; así como la jefatura de los servicios recaudatorios. Y la de contabilidad abarca la coordinación de las actividades contables de la Entidad, la preparación y redacción de la Cuenta general del presupuesto y de la administración del presupuesto; así como el examen e Informe de las cuentas de tesorería y de los valores independientes y auxiliares del presupuesto.

Sin lugar a dudas, el rol desempeñado por los FHN ha hecho de ellos, de un lado, unos verdaderos garantes del cumplimiento del principio de legalidad y, de otro, unos tenaces impulsores de la regeneración democrática de las instituciones locales. En este sentido, se pronuncia Martínez Marín al afirmar que "frente a unas Administraciones cada vez más endogámicas, la decisiva tarea que históricamente han desarrollado, su categoría profesional y sus funciones de fe pública, asesoramiento legal, intervención y auditoría de las cuentas así como la necesaria categorización de las funciones recaudadoras de las Entidades Locales inclinan a defender su existencia y categorizar aún más sus funciones, tanto para dotar a aquéllas de personal profesional cualificado imprescindible en todo gobierno local para realizar su gestión así como por la necesidad de que ésta se realice ajustada a Derecho”"

\section{III.4. LA NUEVA ERA DE LA INTERVENCIÓN LOCAL " ${ }^{11}$}

De entre las tres subescalas, sin duda, la reforma incide muy directamente en la intervención, en particular, en el ejercicio función de control de la gestión económica local que se ve reforzada ex lege —dotándola de mayor independencia y objetividad-con la intención de hacerla depender funcionalmente de la AGE con el objetivo de garantizar la legalidad y control financiero y presupuestario de los EELL ${ }^{112}$. Como apunta Rivero Ortega, el interventor se convierte en un guardián del orden de prioridades en la adopción de decisiones de todo tipo de gastos, protegiendo en el presente y el futuro las disponibilidades suficientes para garantizar la financiación necesaria para los servicios básicos. Siendo el encargado de advertir de los excesos presupuestarios que hipotéticamente amenacen la sostenibilidad de las competencias propias y nucleares de los EELL. Y el secretario, en su función de protección de la legalidad, debe respaldar y reforzar esa advertencia del interventor ${ }^{113}$.

Desde el objetivo de la LRSAL de alejar del ámbito de decisión local la gestión del personal funcionario que desempeña las funciones de control interno, y de garantizar la máxima independencia y autonomía en el control de legalidad y financiero de la gestión y hacienda locales, las funciones de la "intervención" se amplían de forma considerable —al igual que su dependencia del MHAP, como ya se ha señalado— destacándose las siguientes:

a) Valorar de la sostenibilidad financiera de las formas de gestión directa que se propongan para la gestión de un servicio público de competencia local (art. 85.2 LRBRL)

b) Informar el resumen anual del ejercicio de las funciones de control interno respecto de su gestión económica, de los organismos autónomos y de las sociedades mercantiles de ellas dependientes, en sus modalidades de función interventora, función de control financiero, incluida la auditoría de cuentas de las entidades que se determinen reglamentariamente, y función de control de la eficacia que ser emitirá a la IGAE. (art. 213 TRLHL).

c) Elaborar una relación que se incluirá como un punto especial para el orden del día del pleno en el que se debe dar cuenta de todas las resoluciones adoptadas por la alcaldía o presidencia contrarias a los reparos de la intervención (art. 218.1 TRLHL).

d) Elaborar un resumen de las principales anomalías detectadas en materia de ingresos y remisión anual de un informe al Tribunal de Cuentas con todas las resoluciones y acuerdos adoptados por la alcaldía o presidencia y pleno contrarios a los reparos (art. 218.3 TRLHL)

e) Informar la auditoría anual de las cuentas de los consorcios adscritos a su entidad (DF 2.4, que modifica la Ley 26 de noviembre, de Régimen Jurídico de las Administraciones Públicas y del Procedimiento Administrativo Común)

110 MARTÍNEZ MARÍN, A., “La reforma 2003 de los funcionarios locales...”, op. cit., pág. 673.

111 Vid. in totum, FUEYO BROS, F., op. cit., págs. 383-420 y MARTíNEZ PABLO, M., H., “La racionalización y sostenibilidad del nuevo régimen jurídico de los funcionarios con habilitación de carácter nacional tras la entrada en vigor de la Ley $27 / 2013$, de 27 de octubre”, en GARCÍA RUBIO, F. (dir.) Análisis de las repercusiones de la reforma local sobre la organización, competencias y servicios de las entidades locales, Instituto Nacional de Administración Pública (INAP), Madrid, 2015, págs.361-424.

112 En esta línea, el interventor deberá remitir un informe anual con el resumen de dicho control a la Intervención General del Estado (IGAE). Vid. VIVANCOS COMES, op. cit. pág. 247.

113 RIVERO ORTEGA, R., "La evolución histórica de los servicios públicos locales y el papel de los habilitados desde la Constitución de Cádiz hasta nuestros días”, en ORDUÑA REBOLLO, E., MERINO ESTRADA, V. (coord.), op. cit., pág. 627. 
f) Informar previamente el plan de saneamiento individualizado de las entidades del sector público de su entidad que se encuentren en desequilibrio financiero (DA 9 LRBRL)

g) Colaborar con la AGE para realización de actuaciones de apoyo a sus funciones (DA 7 LRSAL).

El refuerzo del rol del interventor es una medida loable y necesaria, sobre todo porque uno de los mecanismos más eficaces para hacer frente al problema de la corrupción es garantizar los correspondientes controles internos y externos para detectar cualquier irregularidad en los procedimientos y actuaciones públicas locales antes de que produzca cualquier consecuencia negativa. No obstante, también debe potenciarse al resto de habilitados estatales, como los secretarios, ya no como una cuestión coyuntural generada por el actual escenario de crisis económica; sino como una exigencia estructural, como núcleo de un sistema estable que otorgue una mayor transparencia, institucionalización y proximidad de los ciudadanos a la Administración local.

En conclusión, esta reforma apunta al fortalecimiento del régimen jurídico de los $\mathrm{FHN}$, reforzando la legitimidad en el ejercicio de las funciones y competencias de los EELL al garantizar y revitalizar los controles internos sobre sus actividades. En palabras de Rivero Ortega "reforzar el papel de secretarios e interventores de la Administración local puede contribuir a racionalizar y optimizar las decisiones económicas municipales, a convertirlos en municipios inteligentes y virtuosos, pero no debieran confundirse tales condiciones con el abstencionismo en el desarrollo de políticas públicas, so riesgo de desnaturalizar la razón de ser prestacional de los entes locales" ${ }^{114}$. Ahora bien, el intento de dotarlos de mayor independencia haciendo únicamente que dependan del Estado, y no de las CCAA, resulta claramente discutible ${ }^{115}$. Aunque es obvio que se debe modificar la estructura del control sobre la actuación de la Administración local en pro de garantizar el cumplimiento de la legalidad, la LRSAL no está dando los pasos en la dirección adecuada, en tanto en cuanto se está aprovechando de esta necesidad para atentar contra la autonomía local, fortaleciendo instituciones, como las diputaciones, cuyos órganos de gobierno adolecen de legitimación democrática directa. En general, Barnés Vázquez señala los efectos perniciosos de este tipo de reformas, al afirmar que "las modas no suelen ser buenas aliadas del análisis jurídico, ni, menos aún, de la serena y fundada construcción dogmática, pues inducen a la tentación de convertir a su objeto en axioma y a su concreción en simple afirmación tautológica, mera expresión de una ideología en boga revestida de técnica" ${ }^{116}$.

\section{III.5. Secretario, Interventor y Tesorero frente al cuerpo político de los entes locales: desajuste entre legalidad y realidad}

El FHN "no es el brazo administrativo de la clase política local”"17. De la LRBRL se desprende que su función primordial es la de garante de la legalidad de la acción y gestión administrativas en beneficio de los ciudadanos. Un control de legalidad diseñado para constituir una fuente de seguridad jurídica y una garantía de los derechos de los ciudadanos frente al caciquismo ${ }^{118}$.

Lo queramos o no, existe una dependencia política de estos funcionarios con una autoridad superior diluida que hace difícil el cumplimiento de ciertas funciones por presiones de distintos actores y pone en entredicho la independencia de las actuaciones de las corporaciones locales. Como ya se ha apuntado, "el sistema fue adulterado paulatinamente por la discrecionalidad implantada a partir de las 'libres designaciones' y otras corruptelas"19, amén del progresivo vaciamiento de competencias de tales funcionarios, especialmente lacerante en las 'grandes poblaciones' ${ }^{120}$, proclives a convertirse, a poco que nos esforcemos, en campo del más tradicional caciquismo, a favor de los partidos políticos y de su bien tupida red de intereses clientelares" ${ }^{21}$.

114 RIVERO ORTEGA, R., “La evolución histórica de...”, op. cit. pág. 628.

115 Así, por ejemplo, el hecho de persistir con la libre designación como modo de selección de estos empleados públicos, y el libre cese de estos funcionarios por los alcaldes en los municipios de gran población.

116 BARNÉS VÁZQUEZ, J., "Procedimientos administrativos y nuevos modelos de gobierno. Algunas consecuencias sobre la transparencia”, en GARCÍA MACHO, R. (ed.), Derecho Administrativo de la información y Administración transparente, Marcial Pons, Madrid, 2010, pág. 51.

117 TOSCAS SANTAMANS, E., op. cit., pág. 3.

118 Ibidem, pág. 3. No obstante, para algunos, nos hallaríamos ante gestores públicos que se encuentran entre funcionarios y políticos, un entorno complejo y cambiante en el que priman intereses interrelacionados, contrapuestos: “El gestor públic hauria de tenir més que cap altre una imatge de rectitud, d'equitat i d'ètica. Les fronteres són difuses, el gestor públic seria l'home del mig, entre polítics i funcionaris, amb un entorn complex i canviant, on primarien interessos interrelacionats, contraposats, amb una diferència substancial amb el sector privat en temes de control, legitimitat i principis". PUJOL I ESTRAGUÉS, H.; RIBA I TORRALBA, J., Els directius públics. Aproximació al seu perfil i a les seves necessitats formatives, Escola d'Administració Pública de Catalunya. Barcelona, 1996, pág. 15.

119 Introducidas a finales de 1991por el Gobierno del Presidente Felipe González.

120 Introducidas a finales de 2003 por el Gobierno del Presidente José María Aznar.

121 SOSA WAGNER, F., "Penalistas y Ayuntamientos", El blog de esPublico, 11 de diciembre de 2007, "Por fin empezamos a enterarnos de lo que significa y del riesgo que supone acabar frívolamente con la independencia de secretarios e interventores en la Administración local española [...]. Porque es el caso que más de doscientos penalistas — catedráticos, magistrados, fiscales— han analizado la corrupción 
No hay que olvidar que la realidad no se corresponde a la legalidad, y por mucho que las leyes establezcan la independencia de los funcionarios, lo cierto es que la lealtad es un valor fundamental entre los funcionarios de altos niveles. Como ponía de manifiesto De la Nuez en un interesante editorial, hemos llegado a un punto en España en que el técnico o profesional ya no es simplemente alguien al que se nombra o con el que se cuenta por sus capacidades y competencias profesionales, sino alguien cuya cualidad más apreciable es la lealtad, que en ocasiones degenera en puro servilismo. Una lealtad hacia la persona que lo nombra, y no hacia la institución ${ }^{122}$. Como afirma Arias Díaz, el funcionario se siente agradecido al político y se ve obligado a prestarle fidelidad administrativa eterna. En ese sentido, toda reforma que refuerce la discrecionalidad en el nombramiento de funcionarios potenciará que se mantenga esa situación de obediencia jerárquica contraria a la independencia de estos trabajadores, ya que saben que su continuidad en el cargo, sus ascensos y su posible cese, no dependerá de la mucha o poca ética que impregne su conducta sino de su fidelidad política ${ }^{123}$. Esto conlleva una desprofesionalización generalizada de la función pública que responde al interés particular en lugar del interés público, un serio problema para el buen funcionamiento de la estructura administrativa, sobre todo cuando se trata de puestos de mayor responsabilidad con facultades de control sobre la Administración, como es el caso de los FHN.

Hay que mirar atrás y recuperar elementos básicos que se van perdiendo de vista con el paso del tiempo. Elementos tales como la significativa distinción entre la estructura de un organismo y su función, pues el servidor público debe ser fiel a esta última, independientemente de lo que digan las personas que formen parte del sistema. Es ahí donde radica la verdadera independencia del gestor público, en ser crítico con su superior y en diferenciar esta cuestión esencial siguiendo su propio criterio, inexcusablemente orientado a la función principal del sector público, en especial al interés general y al buen gobierno, cumpliendo la legalidad y actuando éticamente.

Precisamente ha sido en la Administración local, dónde los FHN fueron los primeros funcionarios en aprobar un "Código Ético" en $2005^{124}$ con el objeto de clarificar las posibles dudas de comportamiento que les pudieran surgir a los miembros de este colectivo en el desarrollo de su actividad profesional ante situaciones en las que no existe una única respuesta correcta. Aunque este tipo de normas de soft law difícilmente podrán conseguir una mejor Administración por sí solos, pero al menos suponen un primer paso decisivo en la dignificación de esta profesión y de sus actuaciones ${ }^{125}$ y por ello "resulta necesario un cambio sustancial, tanto de la sociedad para que castigue las actividades ilícitas como principalmente de los partidos políticos, para controlar, castigar y promover un sistema de entrada al mismo centrado en la meritocracia" ${ }^{126 .}$

Los funcionarios — sean o no FHN_ deben asumir su papel de guardianes de la res publica, y aplicarlo en su gestión para distinguir claramente los intereses de los ciudadanos de los intereses políticos y así actuar a favor de su función como servicio público y no como servicio político. De pensadores como Weber o Tocqueville se desprende la idea de que es necesario trazar una línea clara entre política y Administración dentro de las instituciones del sector público. Para ello es necesario potenciar una “cultura de lo público” y despolitizar la gestión de las Administraciones públicas procurando su mayor profesionalización y respeto a la voluntad legislativa, apartándose de la intencionalidad política imperante. $Y$ todo ello con el objetivo de erradicar la desviación de poder y toda práctica ilegal que sirve de caldo de cultivo de la corrupción y que debe ser combatida desde la profesionalidad, la ética y el sometimiento pleno a la ley y al Derecho ex art. 103.1 CE.

En definitiva, en el Estado español, tanto el "secretario", en su rol de garante de legalidad del conjunto de la actividad administrativa, como el "interventor”, en el suyo de supervisor específicamente de la actividad económica de los EELL —y en general, el conjunto de los FHN — ya desde su creación se constituyen verdaderos "agentes" públicos de prevención de la ilegalidad y de la corrupción que "tienen atribuida la misión de formalizar en Derecho la actividad de los distintos órganos de los Ayuntamientos y Diputaciones, transformando la iniciativa política de los acuerdos adoptados en los correspondientes plenos por los concejales o diputados provinciales, en normas

urbanística en un documento explosivo que tiene gran interés para las Corporaciones locales. Pues bien, ahora los penalistas (... ), sugieren que se refuerce la independencia y autoridad de los órganos técnicos de los ayuntamientos (secretarios, interventores y tesoreros) cuyas facultades se han recortado así como un mayor control de notarios y registradores"”. http://administracionpublica.com/penalistas-yayuntamientos/\#more-406.

122 DE LA NUEZ SÁNCHEZ-CASCADO, E., “Uno de los nuestros”, El Mundo, 7 de agosto de 2012 http://www.elmundo.es/elmundo/ hemeroteca/2012/08/07/t/espana.html.

123 ARIAS DÍAZ, I., op. cit. págs. 98-113

124 Código ético profesional de los secretarios, interventores y tesoreros de administración local, aprobado en la VI asamblea COSITAL, Salamanca, 12-14 de mayo de 2005 http://www.cosital.es/attachments/174_Codigo\%20Etico\%20Cosital.pdf.

125 Para una visión general acerca de la regulación de la ética pública y el rol de los códigos de conductas del personal al servicio de las administraciones públicas, ARMSTRONG, E. "Integrity, Transparency and Accountability in Public Administration: Recent Trends, Regional and International Developments and Emerging Issues”, en Economic \& Social Affairs, Union Nations, 2005, págs. 1-10, disponible en: http:// unpan1.un.org/intradoc/groups/public/documents/un/unpan020955.pdf. Así mismo, FUENTES I GASÓ, J. R., "Buenas prácticas y códigos de conducta...", op. cit., págs. 137-168.

126 JIMÉNEZ GONZÁLEZ, J. L., op. cit., pág. 40. 
municipales o provinciales homologadas en Derecho, o en resoluciones administrativas adoptadas conforme a los requerimientos exigidos por el procedimiento común de las Administraciones públicas y con respeto a los derechos ciudadanos reconocidos en las bases del régimen jurídico de las Administraciones Públicas" 127.

$\mathrm{Y}$, en ejercicio de esta función primordial, la reforma del ordenamiento jurídico local los convierte en los verdaderos "responsables de la función de regeneración democrática" de la organización y las actividades de las administraciones locales.

Como veremos a continuación, exactamente lo mismo es predicable del segretario italiano, que aúna en su persona las funciones más importantes que ejercen los FHN, en particular secretario e interventor. Así, en referencia a España e Italia "cabe decir que durante los mismos años al secretario municipal habilitado por el Estado se le ha intentado 'regionalizar' 128, 'suplantar' ${ }^{129}$, incluso 'suprimir'”' ${ }^{130}$.

\section{EL SEGRETARIO COMO RESPONSABLE DE LA PREVENCIÓN DE LA CORRUPCIÓN LOCAL EN EL ORDENAMIENTO ITALIANO ${ }^{131}$}

La Legge 6 novembre 2012, n. 190, por la que se establecen disposizioni per la prevenzione e la repressione della corruzione e dell'illegalità nella pubblica amministrazone ${ }^{132}$ (Ley 190/2012), conocida como Ley Severino ${ }^{133}$, por primera vez manifiesta un cambio de estrategia en la lucha contra la corrupción en Italia y nos atreveríamos a decir, en el sistema continental administrativo ${ }^{134}$ y con él da cumplimiento a las normas de carácter internacional contra la corrupción ${ }^{135}$. La novedad se debe a que la Ley no plantea hacer frente al fenómeno sólo a través de medidas penales de carácter represivo; sino también empleando instrumentos administrativos de prevención ${ }^{136}$.

127 SÁNCHEZ BLANCO, A., op. cit., pág. 1026.

128 En España, convertir en secretario autonómico: en Italia en secretario regional.

129 En España, mediante el uso creciente en los ayuntamientos de secretarios interinos, no habilitados: en Italia mediante una figura paralela, el director general o City Manager.

130 En España, mediante iniciativas de ciertos grupos políticos y en Italia mediante una propuesta de ley, etc. TOSCAS SANTAMANS; E., op. cit., pág. 4.

131 Sobre la corrupción, vid. in totum, BATTINI, F., "Audizione sul ddl per la prevenzione e represione della corruzione nella P.A.", Giornale di diritto amministrativo (GDA), núm.4, 2012; BENUSSI, C., "La reforma Severino e il nuovo volto della corruzione”, Il coriere del merito, núm. 3, 2013; CAMARDA, L., "Le criticità operative per la realizzazione del piano anticorruzione in comune", Diritto e pratica amministrativa (DPA), núm 5, 2013; “Le nuove responsabilità del segretario comunale”, DPA, núm. 2, 2013; CARLONI, E., "Tendenze recenti e nuovi principi della digitalizzazione pubblica”, GDA, núm. 2, 2015, pág. 148 y ss.; CATALANO, M., “La legge anticorruzione”, DPA, núm 4, 2012;; COSMAI, P., "Il vademecum di Palazzo Vidoni sul responsabile della prevenzione della corruzione e le linee guida del comitato interministeriale", A-P, núm. 4, 2013; DI SERI, Ch., “L'aggiornamento dei programmi triennali per la trasparenza e l'integrita' secondo il D.Igs. n. 33/2013 - II commento”, GDA, núm.1, 2014, pág. 70 y ss.; DOLCINI, E., “Appunti su corruzione e legge anti-corruzione”, Rivista Italiana di Diritto e Procedura Penale (RIDPP), núm.2, 2013; D’URGOLO, G., “Legge anticorruzione: oneri di pubblicità, disciplina degli incarichi extra-istituzionali, responsabilità erariale e responsabilità dirigenziale”, LexItalia.it (LI.it), núm.1, 2013; FOÀ, S., “Le novità delle legge anticorruzione”, Urbanistica e appalti (UA), núm 3, 2013, pág. 293 y ss.; GIUPPONI, T. F., “Il contrasto alla corruzione a cavallo tra due legislature”, Quaderni costituzionali, núm 6, 2013; LADDAGA, G., “La PA dopo la legge anticorruzione”, Guida al pubblico impiego (GPI), núm. 5, 2013; MACRì, M., "Le misure urgenti sulla Pubblica Amministrazione - Le nuove disposizioni in materia di lavoro pubblico, GDA, núm. 11, 2014, pág. 1019 y ss.; MATTARELLA, B. G., "La prevenzione della corruzione in Itaia - II commento", GDA, núm. 2, 2013, pág. 123 y ss.; MASSA, O., "Lo chassé-coisé della retroattività (in margine alla "legge Severino")", Archivio penale (AP), núm. 1, 2014; NIGLIO, N., "La prevenzione del fenomeno della corruzione nella P.A., alla luce della legge n. 190/2012. (Una prima riflessione sui primi 59 commi dell'articolo 1, della legge 6 novembre 2012, n. 190)”, LI.it, núm.1, 2013; PELISSERO, M., “'Nuove' misure di contrasto alla corruzione?”, Diritto penale e processo (DPP), núm. 1, 2015, págs. 5-10; PERIN M., “Legge anticorruzione e gli obblighi del responsabile della prevenzione della corruzione con riferimento alla lesione dell'immagine pubblica”, Ll.it, núm.1, 2013; QUADRELLI, M., "Natura giuridica della Civit, principio del buon andamento e piano triennale di prevenzione della corruzione”, LI.it, núm.9, 2013; ROSI, E., “Corruzione transnazionale e/o corruzione internazionale: una breve riflessione”, DPP, 2013; SANDULLI, M, A., “Le nuove misure di deflazione del contenzioso amministrativo: prevenzione dell'abuso di processo o diniego di giustizia?”, Foro AmministrativoT.A.R. (II), núm. 9, 2012; TUBERTINI, C., “La legge 'Delrio': il riordino del governo locale - ILe norme in materia di unioni e fusioni”, GDA, núms. 8-9, 2014, pág. 786; SEVERINI, “La presunta incostituzionalità del Decreto Severino: tattica dilatoria o dubbio non manifestamente infondato?", Osservatorio dell’Associazione Italiana dei Costituzionalisti, octubre, 2013, págs. 1-15; TESTA; V., "Anticorruzione: come individuare il responsabile della prevenzione”, GPI, núm. 3/2013; “Anticorruzione: in pubblica consultazione le linee guida per l'adozione dei codici di comportamento”, GPI, núm. 10, 2013; “Approvato il Piano nazionale anticorruzione. Ora tocca alle amministrazioni”, GPI, núm. 10, 2013; VERBARO, F., "Quella legge anticorruzione tanto attesa quanto poco efficace”, GPI, núms.1-2, 2013; “Il "peso" della formazione nella lotta alla corruzione”, GPI, núm. 3, 2013.

132 En relación con la aplicación más importante i mediática de esta ley al cavaliere, el exprimer Ministro Silvio Berlusconi, vid. entre muchas, http://periodismointernacional.org/la-ley-severino-echa-a-berlusconi/; http://internacional.elpais.com/internacional/2014/04/10/ actualidad/1397156389_910263.html.

133 Impulsada por el Gobierno técnico del Primer Ministro Mario Monti, se conoce como “Ley Severino” por Paola Severino, Ministra de Justicia, quién redactó el texto junto con Filippo Patroni Griffi, Ministro de Administraciones Públicas y Simplificación.

134 Vid. in totum, CANAPARO, P., "I nuovi protagonisti della lotta alla corruzione nelle pubbliche amministrazioni”, Federalismi.itRivista di Diritto Pubblico Italiano, Comparato ed Europeo, núm. 16, 2010, disponible en: http://www.federalismi.it/nv14/articolo-documento. cfm?artid=23019.

135 Vid. ante notas 11 y 12 en relación al Consejo de Europa o la Naciones Unidas.

136 Vid. COCCIOLO, E. “Las mutaciones del concepto de corrupción...”, op. cit., pág. 21 y ss. 
Más allá de esta referencia al cumplimiento de tratados internacionales, debe señalarse que la adopción de normativas anticorrupción se justifica como un revulsivo necesario en un momento especialmente crítico para la República Italiana. Así la necesidad de tomar medidas contra la "mala administración” no sólo respondía al obvio imperativo de restauración moral; sino también a una imperiosa llamada para restituir eficiencia y credibilidad al sector público en una situación de crisis económica muy aguda. El Estado italiano se encontraba al borde del rescate, por lo que ante los alarmantes estudios realizados por la Unión Europea (UE) y la OCDE sobre la corrupción - Ios cuales estimaban un costo para el Italia de 60 mil millones de euros anuales, equivalente al 3,8\% del PIB ante un promedio del $1 \%$ del conjunto de la UE ${ }^{137}$ — se esperaban señales claras dirigidas no sólo hacia la ciudadanía italiana sino también la comunidad internacional.

\section{IV.1. La emergencia de un verdadero garante de la legalidad y de la prevención de la corrupción}

En este contexto, la Ley Severino actúa primordialmente en tres ámbitos:

1. El establecimiento de una institución anticorrupción, cuyas funciones se asignaron a la Commissione per la valutazione, la trasparenza e l'integrità delle amministrazioni pubbliche (CIVIT) $)^{138}$, luego denominada ${ }^{139}$ como Autorità nazionale anticorruzione e per la valutazione e la trasparenza delle pubbliche amministrazioni (ANAC) ${ }^{140}$.

2. La adopción de medidas específicas y diferenciadas de prevención para cada nivel de administración, a través de dos tipologías de medidas:

a) La adopción de códigos de conducta en cada Administración.

b) Una nueva actividad de planificación ${ }^{141}$ : las administraciones públicas estarán obligadas a aprobar Piani trienali di prevenzione della corruzione (PTPC) sobre la base del Piano nazionale anticorruzione (PNA) que cada año adopta la ANAC a propuesta del Dipartimento della Funzione Pubblica (equivalente al Ministerio de Administraciones Públicas) ${ }^{142}$. Entre los contenidos del PNA cabe destacar, en primer lugar, la funzione di indirizzo de las linee guida a seguir en la elaboración de los PTPC y, en segundo lugar, los criterios de rotación de los empleados públicos, especialmente de los directivos, en los sectores más expuestos a la corrupción y las medidas destinadas a evitar concentración de funciones y cargos de los directivos públicos ${ }^{143}$.

c) El establecimiento de medidas de carácter organizativo: rotación de los cargos, formación del personal en prevención de la corrupción, entre otras, y la que centra nuestro análisis, la novedosa institución de un encargado de prevenir la corrupción ${ }^{144}$.

137 Vid. FONDAZIONE HUME, La corruzione in Italia, disponible en: http://www.lastampa.it/2012/03/24/blogs/datablog/la-corruzione-initalia-3OrOphzQ6wrEcfeidBTjHL/pagina.html.

138 La CIVIT fue instituida por el Decreto Legislativo 27 ottobre 2009, n. 150. Attuazione della legge 4 marzo 2009, n. 15, in materia di ottimizzazione della produttivita' del lavoro pubblico e di efficienza e trasparenza delle pubbliche amministrazioni, medida que adoptaba la llamada "Reforma Brunetta", en ocasión de Renato Brunetta, Ministro para la Administración Pública y la Innovación. Vid., en este sentido, FIDONE, G., "Eficacia y eficiencia en la reforma italiana de la Administración pública (La llamada Reforma Brunetta)", RAP, núm. 186, Madrid, septiembre-diciembre, 2011, págs. 371-388.

139 Art. 5 de la Legge 30 ottobre 2013, n. 125. Conversione in legge, con modificazioni, del decreto-legge 31 agosto 2013, n. 101, recante disposizioni urgenti per il perseguimento di obiettivi di razionalizzazione nelle pubbliche amministrazioni.

140 Esta "autoridad administrativa independiente" no tiene parangón en el Estado español, salvo el caso de Cataluña dónde se equipararía a l'Oficina Antifrau de Catalunya (OAC) creada por la Ley catalana 14/2008, del 5 de noviembre como una entidad/agencia/ autoridad independiente adscrita al Parlamento de Cataluña https://www.antifrau.cat/images/stories/documentos/documents_pdf/ memoria_2014/Memoria-2014.pdf.

141 La implantación de este sistema de planificación se inspira en el modelo instituido a través del Decreto Legislativo 8 giugno 2001, n. 231. Disciplina della responsabilità amministrativa delle persone giuridiche, delle società e delle associazioni anche prive di personalità giuridica, en relación a la responsabilidad (derivada de delito) de las personas jurídicas privadas, en el que la adopción de medidas de prevención de la corrupción a través de un sistema de gestión evita la responsabilidad de la entidad por los delitos cometidos por sus legales representantes, administradores, directivos u otros sujetos sometidos a la dirección o control de los anteriores. Ahora bien, mientras en este modelo las sanciones recaen en la empresa o entidad, en el modelo de la Ley 190/2012 las responsabilidades corresponderán al responsable de la prevención de la corrupción, como se estudiará a continuación.

142 Los PTPC tendrán que identificar las actividades administrativas más expuestas a riesgos de corrupción — “mapa de riesgos de corrupción"-, el grado de implicación del personal al servicio de las administraciones involucrado en tales áreas de actividad, la determinación de las medidas de control y de prevención en función del nivel del riesgo, así como las fórmulas de coordinación en la actuación del plan. Vid. Linee di indirizzo del Comitato interministeriale (d.p.c.m. 16 gennaio 2013) per la predisposizione, da parte del Dipartimento della funzione pubblica, del PNA di cui alla legge 6 novembre 2012, n. 190, disponible en: http://www.funzionepubblica.gov.it/media/1059446/linee _ indirizzo_comitato_interministeriale_anticorruz.pdf; CODARRI, P., SUSIO, B., "Lecco. Il comune è in azione per i piani anticorruzione", A-P, núm. 2, 2013; MERLONI, F., "I piani anticorruzione e i codici di comportamento”, DPA, núm. 8, 2013, pág. 1-19.

143 Vid. ROSSI, A., "I piani per la prevenzione della corruzione in ambito pubblico ed i modelli 231 in ambito privato", Diritto penale e processo, núm. 8, 2013.

144 La principal novedad organizativa de la ley para gran parte de la doctrina: "una politica anticorruzione ha bisogno di organi che si preoccupino di elaborarla e implementarla". MATTARELLA, B., G., op. cit., pág. 125. 
3. La creación del Responsabile della prevenzione della corruzione (RPC) designado, entre los directivos de ruolo di prima fascia, en cada Administración por el órgano de indirizzo politico, que en los EELL será di norma ${ }^{145}$ el segretario, a menos que se proceda a una designación distinta que debe ser objeto de motivación ${ }^{146}$.

No sin suscitar ciertas dudas de constitucionalidad ${ }^{147}$, el Legislador italiano ha sometido también a los EELL a las disposiciones de la Ley 190/2012 sobre la base del principio de imparcialidad ex art. 97 de la Constitución italiana; a pesar de que el reformado art. 117 atribuye al Estado competencia exclusiva sólo en lo que se refiere a las administraciones centrales y a los entes públicos nacionales, reservando la organización a la plena competencia normativa de las regiones y de las propias EELL ${ }^{148}$.

En términos generales, la misión que la Ley ${ }^{149}$ asigna al segretario-RPC se materializa en una función de regulación a través del control y de la planificación de las actuaciones dirigidas a prevenir la aparición de prácticas corruptas dentro de la entidad ${ }^{150}$. En concreto, tendrá que elaborar el PTPC sobre la base del PNA para su aprobación por el órgano di indirizzo politico, es decir, la giunta comunale. En el PTPC se determinarán los objetivos a alcanzar y los sistemas para revisarlos, así como los sectores y concretamente áreas y servicios de la Administración en los que concurre mayor riesgo de corrupción con el fin de establecer las medidas organizativas y los medios necesarios para hacerle frente. En definitiva, nos hallamos ante una herramienta dinámica, no formal, de risk management que implica para el RPC una actividad continuada de supervisión y constante adaptación del plan de la entidad a los problemas detectados y al mantenimiento/consecución de los resultados. Asimismo, tendrá que asegurarse de que tiene lugar correctamente la rotación de los cargos directivos de la entidad; cosa que puede resultar muy complicada porque no está calibrada a la realidad de los comuni o municipios de pequeñas dimensiones, donde no hay nivel directivo y las posiciones de los responsables de servicios no son fungibles. El segretario-RPC tendrá también que definir cuáles son las actividades formativas en materia de prevención de la corrupción y cuál es el personal de la entidad que tendrá que participar en ellas. Ahora bien, el art. 2 de la Ley 190/212 establece la cláusula de la llamada "invarianza financiaría", es decir que todas las medidas aplicativas de la ley así como las actividades de formación no deben suponer nuevos gastos para las administraciones; en otras palabras, la prevención de la corrupción vendría a ser una política de coste cero, una medida de manual dentro del arsenal del desgobierno de lo público descrito de forma meridana por el Prof. Alejandro Nieto; puesto que "la corrupción sigue al poder, como la sombra al cuerpo" ${ }^{151}$.

En cuanto al régimen de la responsabilidad del segretario-RPC, en su condición de responsable anticorrupción de la entidad local, para Mattarella, "si tratterà probabilmente di una responsabilità aggiuntiva rispetto all'incarico già proprio del dirigente (...). Altrettanto probabilmente si tratterà di una responsabilità non particolarmente ricercata dai dirigenti amministrativi, per via dei rischi che essa porterà con sé” ${ }^{152}$. En este sentido, este empleado público se enfrenta a tres distintos supuestos:

145 Esta expresión, “di norma”, según la Circolare del Dipartimento della Funzione pubblica n. 1/2013 comporta el reconocimiento de "una certa flessibilità che consente di scegliere motivate soluzioni gestionali differenziate, giustificate da specificità organizzative". Al mismo tiempo, la circular considera oportuno evitar que el cargo se confie a dirigenti contratados o mediante un encargo de estudios o de asesoramiento excluye el nombramiento de los directivos en las oficinas de la colaboración directa e invita a tener en cuenta las situaciones de conflicto de intereses (por ejemplo, la el responsable de los procedimientos disciplinarios). DI SERI, Ch., op. cit., pag. 75 .

146 Art. 1.7. "A tal fine, l’organo di indirizzo politico individua, di norma tra i dirigenti amministrativi di ruolo di prima fascia in servizio, il responsabile della prevenzione della corruzione. Negli enti locali, il responsabile della prevenzione della corruzione è individuato, di norma, nel segretario, salva diversa e motivata determinazione”. En este mismo sentido se pronunciaba la ANAC: “L'Autorità si è più volte espressa interpretando la disposizione che negli enti locali vuole che il RPC sia di norma individuato nelle figura del segretario comunale o provinciale" en la Relazione annuale 2014 presentada en la Camera dei Deputati el 8 de julio de 2015 , disponible en http:// www.anticorruzione.it/portal/rest/jcr/repository/collaboration/Digital\%20Assets/anacdocs/Attivita/Pubblicazioni/RelazioniAnnuali/2015/ ANAC.Relazione.2014.02.07.15.pdf.

147 Vid. SEVERINI, “La presunta incostituzionalità del Decreto Severino: tattica dilatorio o dubbio non manifestamente infondato?, Osservatorio dell'Associazione Italiana dei Costituzionalisti, octubre, 2013, pàgs. 1-15.

148 A pesar de ello, la garantía institucional de las autonomías territoriales se garantiza a través de un acuerdo de la Conferencia unificada Estado-Regiones-EELL (art. 1.60 de la Ley 190/2012). A pesar de ello, la garantía institucional de las autonomías territoriales se garantiza a través de un acuerdo de la Conferenza Unificata, sede congiunta della Conferenza Stato-Regioni e della Conferenza Stato-Città ed autonomie locali. Vid. per totum, VANDELLI, L., "La participación de los entes locales en las regiones", en FONT LLOVET, T., GALÁN GALÁN, A., (dirs.), Anuario de Gobierno Local 2008, Fundación Democracia y Gobierno Local, Madrid, 2009. Asimismo, vid. http://www.statoregioni.it/ home_UNI.asp?CONF=UNI.

149 Art. 1.8 hasta 14 de la Ley 190/2012.

150 La cuestión de la regulación a través de la función de control, interna a la propia administración, que la doctrina anglosajona denomina "Regulation Inside Government", ha sido tratada por COCCIOLO, E. E., "Corruption control System. Beyond repression: regulation public integrity”, en BALLBÉ, M. ZAGANJORI, X., Comparative view of Administrative Law Issues, AECID, 2010, págs. 510-533.

151 Vid. in totum. NIETO GARCÍA, A., El desgobierno de lo público, Ariel, Barcelona, 2008, pág. 154.

152 MATTARELLA, B., G., op. cit., pág. 125. 
1. El incumplimiento de la obligación de elaboración del PTPC conlleva la aplicación del régimen de responsabilidad de los directivos, cuyas sanciones abarcan la no renovación, la revocación de su nombramiento e incluso, en los supuestos más graves, la "separación definitiva”"153.

2. La comisión de un delito de corrupción en el seno de la entidad declarada por sentencia firme en el seno de la entidad que comporta además de las citadas sanciones, la responsabilidad en vía disciplinaria y por los daños económicos y de imagen de la Administración. Este supuesto se configura a todas luces como de responsabilidad objetiva, podrá eludirla si demuestra la concurrencia de estas dos circunstancias:

a) Que antes de la comisión del delito había predispuesto el PTPC y adoptado todas las medidas de prevención que la Ley prescribe.

a) Que había mantenido la vigilancia sobre la ejecución y el cumplimiento del plan.

3. La violación reiterada del PTPC y el incumplimiento de las obligaciones de control. Un supuesto de responsabilidad derivada de la culpa in vigilando del segretario.

Cuanto se ha expuesto, una vez más, pone al descubierto la dúplice configuración del segretario-RPC de la entidad local en el ordenamiento italiano, por un lado directivo de la entidad local —cuyo régimen de responsabilidad se le aplica- y, por el otro, la clásica de garante de la legalidad de la corporación. Esta bipolaridad se reproduce también desde el punto de vista estructural y funcional, ya que mantiene una relación orgánica con el Ministerio del Interior del que depende, y una relación de servicio con la entidad local, basada en la confianza intuitu personae del sindaco o alcalde que le designa ${ }^{154}$. Esta situación ha sido analizada también teniendo en cuenta la doctrina jurisprudencial, sin llegar a conciliar la disociación intrínseca que caracteriza éste cargo público ${ }^{155}$. Por una parte el Tribunal de Cuentas los considera "garante della legalità e correttezza amministrativa dell'azione dell'ente locale" ${ }^{156}$. Por otra, el mismo tribunal y la jurisdicción contenciosoadministrativa han respaldado la configuración legal del segretario como principal colaborador del alcalde, al tiempo que se permite que éste pueda desempeñar toda una serie de funciones eventuales que le convierten en un autentico city manager público ${ }^{157}$, sin olvidarse la calificación de puntal de la burocracia local de la entidad $^{158}$. Ante esta compleja reconstrucción del puesto público del segretario, que según algunos sufriría de una verdadera "apátrida institucional", se ha llegado a cuestionar la elección del legislador de atribuirle también la condición de RPC ${ }^{159}$. Una duda que se justifica observando que a la atribución de nuevas funciones y responsabilidades no corresponden nuevas potestades: la defensa de legalidad y la prevención de la corrupción continúan persiguiéndose de forma ordinaria a través de las garantías del procedimiento administrativo, de las normas sobre la transparencia y de la nueva actividad de planificación ${ }^{160}$.

El Legislador italiano ha reforzado la citada duplicidad funcional del secretario desde la perspectiva del control económico-financiero del ente local mediante la Legge del 7 dicembre 2012 n. 213. Disposizioni urgenti in materia di

153 Art. 1.8 de la Ley 190/2012 en relación con el art. 21 del Decreto Legislativo 30 marzo 2001, n. 165. Norme generali sull’ordinamento del lavoro alle dipendenze delle amministrazioni pubbliche. La separación sólo puede tener lugar previo expediente disciplinario tramitado por el Ministerio del Interior al que se hallan adscritos.

154 Vid. MEOLI, C., “I segretari comunali e provinciali: dall’Agenzia di nuovo al Ministero dell’interno (comm. a d.I. 31 marzo 2010 , n. 78)”, GDA, núm. 17, 5, 2011, págs. 552-556.

155 ROSSI, C., “Il segretario comunale, riedizione moderna del mito di Atlante”, LeggiOggi.it, 4 de julio de 2012, pág.1, http://www. leggioggi.it/2012/07/04/il-segretario-comunale-riedizione-moderna-del-mito-di-atlante/.

156 Corte dei conti, Sez. giur. Toscana, sentenza n. 217 del 7 maggio 2012.

157 Vid. arts. 97 y 108.4 del Decreto Legislativo 18 agosto 2000, n. 267, Testo unico delle leggi sull'ordinamento degli enti locali. "Le funzioni di direttore generale, possono, in alternativa, essere attribuite dal sindaco/presidente della provincia al segretario comunale o provinciale, possibilità prevista in ogni tipo di ente a prescindere dalla dimensione e senza neppure traccia di preventiva deliberazione giuntale." SILVESTRO, C., "Il fluttuante orientamento attorno la figura del city manager", Diritto\&Diritti, febrer, 2002. Disponible en http://www.diritto.it/articoli/ amministrativo/silvestro4.html.

158 "Non sarebbe forse il caso di puntare su una nuova figura di dirigente generale dell'Ente, che sicuramente non potrà identificarsi con la figura tradizionale del segretario comunale, ma forse neppure con quella troppo frettolosamente costruita del direttore generale?". PANASSIDI, G., “Alcune riflessioni critiche sulle figure di vértice dell'organizzazione amministrativa dei comuni e delle provincie: segretario comunale e direttore generale”, Giustam, núm. 4, 2001. Disponible en http://www.giustamm.it/cds1/articoli/panassidi_segretari.htm. Vid. MELE, R., STORLAZZI, A., “La funzione di direzione generale nel Comune:il ruolo del segretario comunale”, Azienda Pubblica, 5, 1997, pág. $473-485$.

159 “E' dunque una oggettiva condizione di apolidia istituzionale che pesa maledettamente su questa figura, figlia spuria di un ordinamento che stenta a coordinare collocazione istituzionale ed attribuzioni funzionali di questa strana professione". ROSSI, C., op. cit., pág.1.

$160 \mathrm{Y}$ ello, toda vez lo que el único y verdadero instrumento extraordinario en las manos del secretario, la [desmesurada] potestad de control previo de legitimidad, fue suprimida la Riforma Bassanini (Art. 21 y ss, de la Legge 15 maggio 1997, n. 127. Misure urgenti per lo snellimento dell'attività amministrativa e dei procedimenti di decisione e di controllo) 
finanza e funzionamento degli enti territoriali — Ley $213 / 2012$ — ${ }^{161}$, que viene a modificar profundamente el sistema de controles internos existentes hasta el momento en los entes locales; puesto que añade a la primigenia función de gestión económica una función de carácter inspector que deriva del rol de RPC ${ }^{162}$, que le atribuye la Ley 190/2012 ${ }^{163}$.

Tal vez antes de encomendar una nueva misión a los secretarios, el Legislador italiano debiera plantearse una revisión de la relación compleja que une a estos funcionarios con la AGE y fiduciariamente con la entidad local a través de su alcalde o presidente ${ }^{164}$. En todo caso, el concepto y funciones de este empleado público local se mantienen desdibujados, tal y como afirma Carlone, "il segretario comunale, segna in questo senso il rischio di uno sviluppo "compartimentale" delle riforme amministrative e ne prefigura, quindi, l'inevitabile ridimensionamento nell'ottica di una più generale modernizzazione dell'amministrazione ed evoluzione del rapporto con il cittadino." 165

De la suma de la Ley 190/2013 y de la Ley 213/2012 "emerge con chiarezza la volontà del legislatore di valorizzare la figura e il ruolo del segretario comunale caricandolo di responsabilità che si ricollegano a importanti poteri di direzione e di controllo sull'attività dell'ente" ${ }^{166}$. Así, para MEOLA, el segretario cumple a la vez las funciones de garante de la legalidad, de manager y de civil servants ${ }^{167}$ y todas ellas debe desarrollarlas bajo el prisma de la prevención de la corrupción.

\section{IV.2. El cénit del segretario comunale y provinciale}

A pesar de lo dicho hasta ahora, como nota final, hay que hacer mención a la supresión de esta centenaria institución. En la carta abierta que el Presidente del Consiglio italiano y la Ministra de Administraciones Pública, Matteo Renzi y Marianna Madia, dirigieron en abril 2014 a los empleados públicos para exponer las claves de la reforma de la Administración pública que el ejecutivo deseaba impulsar, de entre las 44 medidas propuestas, la medida decimotercera establecía la "abolizione della figura del segretario comunale" ${ }_{168}$. El aluvión de críticas y las presiones sindicales recibidas en un primer momento hicieron retroceder al Gobierno, que aseguró que no la suprimiría ${ }^{169}$. Sin embargo, tras la adopción de una primera medida que circulaba por los pasillos de Palazzo Chigi: la creación de un registro único para el secretario y el "directivo superior" o "dirigente apicale" con contrato laboral en el ámbito local ${ }^{170}$, finalmente el Parlamento italiano, para dar cumplimiento a la llamada "Reforma Madia" ha aprobado la Legge 7 agosto de 2015, núm. 154, Deleghe al Governo in materia di riorganizzazione delle amministrazioni pubbliche ${ }^{171}$. En virtud de esta delegación legislativa, el gobierno tendrá que adoptar en el plazo de doce meses desde su entrada en vigor, los decretos legislativos necesarios para establecer el régimen jurídico del dirigente apicale sobre la base de los criterios y principios establecidos en la propia Ley 154/2015; entre ellos, cabe destacar las previsiones en materia de entes locales, que establecen la abolición de la figura del segretario comunale y provincialel —art 11.1.a.4 de esta Ley—. Así, según esta disposición, se transfieren a los directivos

161 Conversión en ley, con modificaciones, del Decreto-legge 10 ottobre 2012, n. 174. Disposizioni urgenti in materia di finanza e funzionamento degli enti territoriali, nonché ulteriori disposizioni in favore delle zone terremotate nel maggio 2012.

162 CAMARDA, L., "Le nuove responsabilità del segretario comunale”, Diritto e pratica amministrativa, febrero, 2013, pag. 38. Vid. asimismo RUFFINI, R., "L'evoluzione del sistema dei controlli interni negli enti locali alla luce della legge n. 190/2012 in tema di corruzione", A-P, núm.1, 2013.

163 Para algunos, esta nueva vertiente justificaría la conversión del secretario en un órgano de control verdaderamente independiente situado fuera del ente local en la Prefettura-Ufficio Territoriale del Governo, órgano periférico del Ministero dell’Interno, "Per tali ragioni, una soluzione in grado di dribblare tali rischi ed evitare le potenziali distorsioni ed elusioni normative potrebbe essere proprio quella di "estrarre" la figura dei segretari comunali dalle stesse strutture organizzative degli enti locali affinché, costituendoli in pool o team autonomi, operanti in comprensori ampi, magari alle dipendenze dirette delle Prefetture, essi possano svolgere una efficace azione di controllo collaborativo e preventivo." SORGENTE, N., "Il rafforzamento del sistema dei controlli interni negli enti locali alla luce del D.L. 174/2012 e i suoi riflessi sullo status del segretario comunale.”, Rivista Giuridica AmbienteDiritto.lt, 2012, pag. 13, http://www.ambientediritto.it/home/oad/il-rafforzamentodel-sistema-dei-controlli-interni-negli-enti-locali-alla-luce-del-dl-1742012-e.

164 Vid. DAVID, D., LEPORE, V., "La legge anticorruzione: novità e limiti applicativi negli enti locali”, Amministrazione in Cammino, 05/07/2013, disponible en: http://www.amministrazioneincammino.luiss.it/?p=20149.

165 CARLONI, E., op. cit. pág. 149-150.

166 CAMARDA, L., op. cit., pág. 42.

167 MEOLA, A., "Il ruolo del segretario nei nuovi controlli interni degli enti locali tra management, legalità e civil servants", Azienditalia, núm. 3, pag. 2013, pag. 102.

168 El texto íntegro de la carta: http://www.governo.it/Governolnforma/Documenti/lettera dipendenti_pubblici.pdf.

169 A pesar de ello, el art. 10 de la Legge 11 agosto 2014, n. 114. Conversione in legge, con modificazioni, del Decreto-legge 24 giugno 2014, n. 90. Misure urgenti per la semplificazione e la trasparenza amministrativa e per l'efficienza degli uffici giudiziari suprimió las tasas por el ejercicio de la función pública del secretario comunal y provincial.

170 TURRINI, D., “PA, i segretari comunali contro il governo: No all'albo unico con i direttori generali”, II Fatto Quotidiano, 27 de junio de 2014, http://www.ilfattoquotidiano.it/2014/06/27/comuni-segretari-comunali-contro-il-governo-vuole-unico-albo-con-dg-di-fiduciasindaci/1039624/

171 El proyecto de ley fue presentado por el Gobierno en el Senato el 23 de abril de 2014. Aprobado por el Consiglio dei Ministri el 10 de julio de 2014. Aprobado por el Senado el 30 de abril de 2015. Finalmente, aprobado por la Camera dei Deputati con mínimas diferencias el 17 de julio de 2015 (DDL n. C-3098), por lo que retorna a la Cámara Alta, aunque su promulgación en ya casi indudable. A pesar de ello, los EEL deberán designar a un "dirigente apicale" con las funciones de aplicación de l’indirizzo politico, coordinación de la actividad administrativa y control de legalidad de la actuación administrativa. 
locales "[i] compiti di attuazione dell'indirizzo politico, coordinamento dell'attività amministrativa e controllo della legalità dell'azione amministrativa", funciones desempeñadas hasta el momento por el secretario; mientras que se prevé que éste mantenga "le funzione rogante in capo ai dirigenti apicali aventi i prescritti requisiti".

Desde un punto de vista organizativo, desaparece el registro nacional o "albo nazionale dei segretari" y se establece que los secretarios actualmente inscritos a las categorías - fasce professionali- A y B, pasen automáticamente a pertenecer al cuerpo único — ruolo unico — de "dirigenti degli enti locali", creado por esta Ley; para aquellos secretarios inscritos a la categoría C y para los que eventualmente hayan superado el concurso de acceso al cuerpo secretarial, se prevé la inclusión en el citado nuevo cuerpo una vez transcurridos dos años de ejercicio efectivo de las funciones de secretario o equivalentes.

En cualquier caso, durante el período inicial y hasta el límite de tres años desde la entrada en vigor del decreto legislativo que regulará esta materia, los EELL que no cuenten con un "director general" con la condición de "directivo superior de la corporación" deberán asignarla a un miembro del cuerpo de secretarios o a alguien que hay superado el concurso de acceso a dicho cuerpo.

Esta decisiva reforma, que ha levantado polémicas políticas e institucionales ${ }^{172}$, se ha encontrado con importantes resistencias también en una parte de la doctrina iusadministrativista ${ }^{173}$, además de las enérgicas protestas de los propios secretarios, quienes simbólicamente remitieron los nombramientos como RPC y de la transparencia al Presidente de la República y a los de las dos cámaras del Parlamento ${ }^{174}$.

En cualquier caso, aunque la Ley 154/2015 no establezca nada de manera específica en este ámbito, y a la espera del desarrollo legislativo, debe recordarse que la Ley Severino, al establecer la creación del RPC, afirmaba que éste tenía que ser designado entre los directivos di prima fascia en cada Administración y que en los EELL sería normalmente el segretario quién asumiría la condición del RPC, salvas excepciones motivadas. La transformación del secretario en dirigente apicale viene a garantizar la continuidad de las funciones en el nuevo órgano, de la misma manera que en las demás administraciones públicas —y con los mismos problemas de independencia-, consolidando la figura general del ethics officer norteamericano a la que hicimos anteriormente referencia.

\section{CONSIDERACIONES FINALES}

Este artículo ha pretendido analizar el más reciente tratamiento de urgencia que ha querido aplicarse a la débil y deteriorada salud democrática de nuestras instituciones. Una ambiciosa reforma, en el caso español, con un conjunto de medidas drásticas que por lo general no son coherentes con su cometido, pues la necesaria regeneración democrática pasa por dar más protagonismo al mundo local como contexto idóneo para la innovación institucional, y no por la voluntad recentralizadora a la que tiende cada vez más el Gobierno español, con independencia del color político que rija sus intereses.

El "derecho a una buena administración”, consagrado por la UE 175, exige que antes de adoptar una decisión los poderes públicos deben ponderar de forma diligente todos los intereses implicados y los derechos que puedan verse afectados negativamente por esa futura decisión, además de sustentarla en datos suficientes y reales que la justifiquen, más allá del liberalismo implacable, para algunos. De modo que a la hora de decidir "recortes públicos" sobre elementos o prestaciones que afecten el núcleo de los derechos fundamentales, esgrimir únicamente el ahorro económico no es razón suficiente para este nuevo parámetro de la actuación administrativa.

A estas alturas, no queda duda alguna de que la LRSAL pone de manifiesto la desconfianza estatal hacia el mundo local, y por ello limita el margen de maniobra y la capacidad de decisión de los entes municipales a favor de un mayor control por parte de la AGE que tiene, como uno de sus medios más potentes, a los FHN al servicio de las EELL. Y todo ello, bajo la excusa de la "contención presupuestaria" que eufemísticamente

172 Acerca del debate en la Comisión Asuntos Constitucionales del Senado en sede de aprobación de la Reforma Madia, vid. http:// segretaridellazio.blogspot.dk/2015/04/la-commissione-affari-costituzionali.html. En el mismo sentido, el Presidente de la ANAC, Raffaele Cantone, expresó en una reunión de alcaldes contra la Camorra, celebrada en Santa María Capua Vetere, el 16 de febrero de 2015 su perplejidad por la abolición de los secretarios comunales, afirmando que parece poco coherente con el propósito de potenciar la normativa anticorrupción la eliminación de tales órganos que se configuran como puntales fundamentales del modelo de prevención de la corrupción además de ser órganos de garantía de la coordinación de la actividad administrativa y especialmente de la legitimidad de las actuaciones de las entidades locales. En este sentido, afirmaba que "la presenza del Segretario comunale garantisca nei comuni del sud ai Sindaci anche di resistere a 'certe pressioni”'. Vid. http://segretaridellazio.blogspot.com.es/2015/03/tutti-contrari-allabolizione-dei.html.

173 La Asociación Profesional de los Secretarios Comunales y Provinciales promovió un manifestó contra la abolición del cuerpo, firmado por un varios catedráticos de Derecho Administrativo, el documento puede ser consultado en: https://drive.google.com/file/d/oBz1KI BGRZZrnb3ZHZGdiXzJoM19XYWdaYllsR3FjckNHRzMo/edit.

174 Vid. CATANIA, L., “I segretari comunali lasciano l’anticorruzione?” en LeggiOggi.it, del 7 de mayo de 2015 , disponible en: http:// www.leggioggi.it/2015/05/07/i-segretari-comunali-lasciano-lanticorruzione/

175 Art. 41 de la Carta de Derechos Fundamentales de la UE, regulado implícitamente en la CE, arts. 9.3, 31.2 y 103.1. Asimismo, el art. 22 del Estatuto de Autonomía de Cataluña.

REALA, n 4, julio-diciembre 2015, ISSN: 1989-8975 - DOI: http://dx.doi.org/10.24965/reala.voi4.10305 
se ha venido a denominar: "estabilidad presupuestaria y sostenibilidad financiera" que cual "bálsamo de Fierabrás" debe sanar a una Administración local supuestamente "derrochadora" y "arruinada". Unos conceptos "economicistas" que han pasado, desacertadamente, a convertirse en el principio básico y fundamental a la hora de atribuir competencias a las EELL. Así para Carrillo Donaire y Navarro Rodríguez, "reconducir desde el principio de sostenibilidad financiera el mapa competencial local y el ejercicio de la potestad de autoorganización puede resultar paradójico cuando las desviaciones de déficit publico derivadas del gasto local son realmente insignificantes sobre el total del sector público"176. Y todo ello, obviando que la contención del déficit público no tiene por qué reñir con la cercanía de la gestión administrativa a los ciudadanos y la transparencia. Y es que "Ios mecanismos de transparencia se han ido incorporando en nuestro ordenamiento jurídico local a través de las sucesivas reformas normativas cuya finalidad principal ha sido, precisamente, la lucha contra la corrupción" ${ }^{177 .}$

Ahora bien, la aplicación de esta Ley choca con una importante resistencia por parte del municipalismo organizado, sobretodo por el menoscabo flagrante del principio de autonomía local, que ha motivado su impugnación ante el Tribunal Constitucional ${ }^{178}$. A pesar de que la doctrina había reiterado la necesidad de una reforma profunda del régimen local, y no únicamente de las administraciones locales, esta Ley se ha quedado en un conjunto de medidas sesgadas y parciales, que adolecen de falta de transversalidad, consenso e intensidad, en muchos casos.

Asimismo, detrás de esta reforma se percibe una gran desconfianza en los empleados públicos del ámbito local, de ahí ese excesivo control en su actividad y ese desmantelamiento de sus funciones. No obstante, los EELL han demostrado ser merecedores de confianza suficiente como para reconocer su autonomía y responsabilidad, puesto que cumplen una función primordial para la gestión pública, y como su implicación en las necesidades ciudadanas y la prestación de un servicio público real y de calidad.

Uno de los aspectos más destacados de la LRSAL es el fortalecimiento de la posición de los FHN reforzándose de este modo la legitimidad de la actuación local, habida cuenta que se garantizan y revisan los controles internos. Sin embargo, se incrementa la dependencia funcional de la AGE, en detrimento de la de las CCAA, bajo el argumento, de garantizar una mayor independencia y objetividad de este colectivo, cosa que es, en nuestra opinión, es muy discutible. En particular, se refuerza considerablemente el control interno a través del interventor general, y para ello se amplían considerablemente sus funciones, a la vez que se convierte en un delegado en el ente local con el deber de suministrar toda la información relevante al MHAP, con el fin de que tenga un conocimiento exacto y puntal de la gestión económica de los EELL ${ }^{179}$.

La Ley se orienta en la dirección correcta, pero ello no debería realizarse a costa de limitar la autonomía local, su iniciativa y capacidad innovadora. Lo más lamentable de la LRSAL es el caso omiso que presta a la profundización de la democracia local, pues en lugar de potenciarla, concentra un mayor poder en las diputaciones provinciales, entes que no gozan de legitimidad democrática directa, a diferencia de lo que ocurre en el ámbito municipal. Todo ello supone ir, sin duda, en la dirección contraria al empowerment de la ciudadanía y de la representatividad de sus intereses ${ }^{180}$.

No obstante, más allá del desacuerdo en tal "intensificación vicarial” del rol estatal, podría discutirse que se refuerce más a los interventores que al resto de $\mathrm{FHN}^{181}$; así como el mantenimiento de la libre designación que supone un filtro poco efectivo a la hora de impedir los actos y acuerdos ilegales que vulneren el interés

176 Y continúan: "Difícilmente se le puede achacar a los Municipios, y muy especialmente a los pequeños, la responsabilidad de la abultad deuda pública”. CARRILLO DONAIRE, J. A., NAVARRO RODRÍGUEZ, P., “Introducción”, en CARRILLO DONAIRE, J. A., NAVARRO RODRÍGUEZ, P., op. cit., pág. 18.

177 CERRILLO I MARTÍNEZ, A., "Transparencia administrativa y lucha contra la corrupción en la Administración local”, en FONT LLOVET, T., GALÁN GALÁN, A., Anuario de Gobierno Local 2011. Gobierno Local: ¿crisis o renovación?, Fundación Democracia y Gobierno local, Madrid, abril 2012, pág. 297.

178 Conflicto en defensa de la autonomía local núm. 4292-2014 (BOE, núm. 223 de 13 de septiembre de 2014.

179 A título de ejemplo, destaca la atribución de la nueva función de gestión tributaria que no se le reconocía hasta ahora y la elaboración de diversos informes, como el informe anual de auditoría de las cuentas de los consorcios adscritos a su entidad, el informe resumen de los controles de calidad de los servicios prestados por la entidad municipal o el informe previo al plan de saneamiento individualizado de las entidades del sector público en caso de que la entidad se encuentre en situación de déficit.

180 Así "con carácter general podemos decir que nos encontramos ante una reforma de voluntad loable; pero demasiado larga en su tramitación (...), y que requiere una enorme precisión en cuanto a la concreción de los mecanismos implantados”. GARCíA RUBIO, F., “La provincia como entidad local. Un análisis tras la Ley de Racionalización”, en SANTAMARÍA PASTOR, J. A. (coord.), op. cit., pág. 303.

181 La propia Federación Española de Municipios y Provincias (FEMP) ha señalado a su juicio, el papel que el texto otorga a los interventores excede de las responsabilidades de propias de un funcionario, entrando en terreno la decisión política sobre el ámbito competencial de los EELL. Así, en fecha 29/04/2013, http://www.femp.es/Portal/Front/ContenidoDetalle/_fxSSGDnKJVmHONf6iLM8gxzAJ_31y oKWQEJAGVCRDF8. 
general y que pueden entrañar alguna forma de corrupción ${ }^{182}$. Una libre designación que, entre otros factores, no provoca más que desprofesionalización y dependencia del funcionario respecto del poder político, en una vuelta al spoil system propia del siglo XIX ${ }^{183}$, que para algunos los convierte en "ostaggio dei sindaci" 184 . Y para otros en "comisarios" fiscalizadores del poder central. En cualquier caso, "la lealtad al interés general, esencia del servicio público, no es algo que sólo interese a los funcionarios y a los políticos que desean ser honestos. La propia ciudadanía está concernida" ${ }^{185}$.

$\mathrm{Y}$, es que, "el secretario [el interventor y el tesorero] municipal ha sido históricamente en España —al igual que [el segretario] en Italia - una figura importante de la Administración local, pero ha sufrido en las dos últimas décadas un notable debilitamiento, lo que incide negativamente no sólo en el colectivo funcionarial y en la Administración, sino también en la ciudadanía" ${ }^{186}$. Así, en palabras de Sosa Wagner, es preciso "que se intente restablecer el honor perdido de los secretarios, interventores y tesoreros como consecuencia de los manejos políticos que estos funcionarios — indispensables si queremos un Administración honesta y acomodada a la leyhan padecido" 187 . Un proceso paulatino que en el caso de Italia le ha llevado a la extinción.

Por último, no debemos olvidar que la función pública está sometida a una gran responsabilidad social en el desarrollo de su actividad, lo que implica cuestiones éticas muy relevantes. La situación actual de incongruencia entre los principios y valores del ordenamiento jurídico que proclaman las administraciones y su actuación demuestra que los instrumentos con que se cuenta en este sentido no son suficientes para garantizar la existencia de un cuerpo de profesionales preparados para afrontar el reto de servir con objetividad los intereses generales, con independencia, imparcialidad y respeto a la Ley.

La aspiración a formar parte del servicio a la res publica debería ser querida y vivida como una manifestación del principio de compromiso con el bien común, como la participación personal en el proyecto común de gobierno, en el esfuerzo conjunto por el progreso social. Así, en cualquier puesto de trabajo de la Administración pública se requiere que los empleados reúnan las condiciones de integridad, capacidad de juicio, independencia de criterio y actuación ética, inherentes a los valores de conciencia cívica y de responsabilidad social al servicio del conjunto de la ciudadanía que les protegen de la actuación interesada, de la satisfacción de interés privado propio o ajeno sobre el público y, en definitiva, de prácticas ilegales y corruptas.

Esta es una lucha en la que no sólo los FHN tienen un papel decisivo; sino que a ella deben comprometerse el conjunto de las instituciones públicas de un Estado. Así, “en aras de una mayor eficacia en la prevención y lucha contra el fraude fiscal y la corrupción, se aconseja reforzar la vigilancia y endurecer los controles institucionales ejercidos por distintos organismos, desde la Secretaría General, la Intervención y las auditorías externas, hasta la Agencia Tributaria, la Fiscalía Anticorrupción y el Tribunal de Cuentas, así como los organismos de control del fraude y la corrupción del ámbito autonómico" ${ }^{188}$.

La respuesta penal a esta problemática es necesaria, pero insuficiente, "la utilización de técnicas de represión como única y exclusiva vía para combatir la corrupción, a la larga produce más decepciones que satisfacciones” ${ }^{189}$. Lo realmente interesante en este ámbito es la función preventiva del Derecho Administrativo, y no tanto la represiva por los incumplimientos que puedan surgir. Se debe actuar sobre el mismo origen del fenómeno de la corrupción en lugar de centrarse sobre sus deplorables consecuencias, a través de la incorporación de medidas efectivas en los procedimientos administrativos y en el conjunto de las actuaciones públicas de los EELL, bajo el control y supervisión administrativos y económicos de funcionarios "probos" e "independientes" como el segretario italiano o nuestros $\mathrm{FHN}^{190}$.

182 La propia Federación Española de Municipios y Provincias (FEMP) ha señalado a su juicio, el papel que el texto otorga a los interventores excede de las responsabilidades de propias de un funcionario, entrando en terreno la decisión política sobre el ámbito competencial de los EELL. Así, en fecha 29/04/2013, http://www.femp.es/Portal/Front/ContenidoDetalle/_fxSSGDnKJVmHONf6iLM8gxzAJ_31y oKwQEJAGVCRDF8.

183 URQUIZA MORALES, J. M., op. cit., págs. 82-84.

184 ROSSI, C., op. cit., pág. 1.

185 TOSCAS SANTAMANS, E., op. cit., pág. 6.

186 Ibidem, pág. 1.

187 SOSA WAGNER, F., “Prólogo”, en CARRILLO DONAIRE, J. A., NAVARRO RODRíGUEZ, P., op. cit., pág. 15.

188 Grupo Parlamentario de IU, ICV - EUiA, CHA. La Izquierda Plural, "Proposición no de ley sobre un Plan Integral para la regeneración democrática y la lucha contra la corrupción”, http://www.izquierda-unida.es/sites/default/files/doc/45_Medidas_Contra_Corrupcion.pdf, BOCG, X Legislatura, CD, núm. 555, de 7 de noviembre de 2014, pág. 12. En el caso de Cataluña, deberíamos añadir la OAC, vid. ante, nota 119.

189 COCCIOLO, E. E., “Las mutaciones del concepto de corrupción...”, op. cit., pág. 37.

190 De ahí “su preocupación por la “corrupción urbanística” (manifestada, entre otras cosas, con su actitud de ponerse incondicionalmente a disposición de la Fiscalía Anticorrupción, y proponer alternativas)”. ÁVILA CANO, E., “El control de secretarios e interventores municipales", en AA.VV. Urbanismo y democracia. Alternativas para evitar la corrupción, Fundación Alternativas, Madrid, 2007, págs. 121-130. 
En definitiva, el secretario, el interventor y el tesorero españoles y el segretario —o, ahora el digirente apicaleitaliano ejercen un conjunto de funciones esenciales para el desarrollo de la actividad de los entes locales del siglo XXI en un Estado del bienestar, "con miras al interés general" ${ }^{191}$, desde la profesionalidad, la transparencia, la eficiencia, la eficacia, la ética y la legalidad. Y ello, no sólo por exigencia legal; sino y sobre todo por exigencia y por respeto a la ciudadanía a la que se deben los "servidores públicos".

\section{BIBLIOGRAFIA}

AA.VV., “La revisión del Gobierno y la Administración local en la Ley 27/2013”, Cuadernos de Derecho Local (QDL), núm. 34 extraordinario, Fundación Democracia y Gobierno Local, Madrid, febrero, 2014.

AGIRREAZKUENAGA ZIGORRAGA, I., Origen de los funcionarios locales de habilitación estatal: los cuerpos nacionales, Instituto Vasco de Administración Pública, Oñati, 1996.

ALDEGUER CERDÁ, B., "Ética pública y gobierno local en un contexto de crisis económica”, Barataria, Revista Castellano-Manchega de Ciencias Sociales, núm. 15, 2013.

ALMEIDA CERREDA, M., "La reforma de la planta, estructura competencial, organización y articulación de la Administración local”, en DíEZ SÁNCHEZ, J. J., (Coord.), La planta del Gobierno local, Asociación Española de Profesores de Derecho Administrativo, Fundación Democracia y Gobierno Local, Madrid, 2013.

ARIAS DÍAZ, I., "Chequeo a la Administración pública y propuesta de código ético y de buenas prácticas”, Revista Jurídica de Asturias, núm. 35, 2011.

ARMSTRONG, E., "Integrity, Transparency and Accountability in Public Administration: Recent Trends, Regional and International Developments and Emerging Issues”, Economic \& Social Affairs, Union Nations, 2005.

ÁVILA CANO, E., "Democracia y gobierno local: La aportación de los secretarios, interventores y tesoreros de la Administración Local a su historia reciente", en ORDUÑA REBOLLO, E., MERINO ESTRADA, V. (coord.), Secretarios, interventores y tesoreros de la administración local: doscientos años al servicio de la ciudadanía, Consejo General de Colegios de Secretarios, Interventores y Tesoreros de Administración Local (COSITAL), Madrid, 2012..- "El control de secretarios e interventores municipales", en AAVV., Urbanismo y democracia. Alternativas para evitar la corrupción, Fundación Alternativas, Madrid, 2007.

ÁVILA RODRÍGUEZ, C. M., GUTIÉRREZ RODRÍGUEZ, F. (coords.) El derecho a la buena administración y la ética pública, Tirant lo Blanch, Valencia, 2011.

BALLBÉ MALLOL, M., “El futuro del Derecho Administrativo en la globalización: entre la americanización y la europeización”, Revista de Administración Pública (RAP), núm. 174, Madrid, septiembre-diciembre 2007.

BALLBÉ MALLOL, M., FUENTES i GASÓ, J. R., "Nous principis i capacitats competencials", en II Congrés de Municipis de Catalunya. Una aposta de futur, Barcelona, 2003.

BARNÉS VÁZQUEZ, J., "Procedimientos administrativos y nuevos modelos de gobierno. Algunas consecuencias sobre la transparencia”, en GARCÍA MACHO, R. (ed.), Derecho Administrativo de la información y Administración transparente, Marcial Pons, Madrid, 2010.

BASSOLS COMA, M., "La racionalización de la administración local en el marco de la sostenibilidad, financiera, panorama general”, QDL, núm. 34 extraordinario, Fundación Democracia y Gobierno Local, Madrid, febrero, 2014.

BATTINI, F., “Audizione sul ddl per la prevenzione e represione della corruzione nella P.A.”, Giornale di diritto amministrativo (GDA), núm.4, 2012.

BELLIGNI, S., “Corruzione, malcostume amministrativo e strategie etiche. II ruolo dei codici”, en Working Papers del Departamento de Ciencias Políticas «Polis», Universidad del Piemonte Oriental «Amedeo Avogadro», Torino, 1999.

BENUSSI, C., "La reforma Severino e il nuovo volto della corruzione”, Il coriere del merito, núm. 3, 2013.

BRIOSCHI, C. A., Breve storia della corruzione dall'età antica ai giorni nostri, Tea, Milán, 2004.

BRUGUÉ TORRUELLA, J., GALLEGO CALDERÓN, R., “Actituds i habilitats en els gerents públics (locals) del segle XXI", en Repensar el paper del gestor públic en el segle XXI. Actes del I Congrés Català de Gestió Pública, Escola d’Administració Pública de Catalunya, Barcelona, 2003.

CAMARDA, L., "Le criticità operative per la realizzazione del piano anticorruzione in comune", Diritto e pratica amministrativa (DPA), núm 5, 2013.

CAMARDA, L., "Le nuove responsabilità del segretario comunale”, Diritto e pratica amministrativa (DPA), febrero, 2013.

191 Acerca del interés general entendido como cuestión esencial del derecho administrativo y finalidad última de la acción pública, vid. RIVERO YSERN, E.; RODRÍGUEZ-ARANA MUÑOZ, J., Con miras al interés general, Derecho Público Global, Madrid, 2014 , pág. 11 para quiénes “Afirmar que existe un interés general por encima de los intereses particulares, que existe un interés social, de todos, que es superior moralmente a los intereses de las diferentes partes, es la tarea que debe presidir el quehacer del Estado y de los diferentes entes territoriales que lo componen." 
CAMPOS DAROCA, J. M., La reforma de la Ley de bases de régimen local: Ley 27/2013, de 27 de diciembre, Bosch, Barcelona, 2014.

CANAPARO, P., “I nuovi protagonisti della lotta alla corruzione nelle pubbliche amministrazioni”, Federalismi.itRivista di Diritto Pubblico Italiano, Comparato ed Europeo, núm. 16, 2010.

CANTERO MARTÍNEZ, J., "Reforma local y función pública. El nuevo régimen de los funcionarios locales con habilitación de carácter nacional”, en QUINTANA LÓPEZ, T. et alter, La reforma del régimen local. Comentario a la ley 27/2013, de 27 de diciembre, de racionalización y sostenibilidad de la administración local, Tirant lo Blanch, Valencia, 2014.

CARLONI, E., “Tendenze recenti e nuovi principi della digitalizzazione pubblica”, GDA, núm. 2, 2015.

CARRILLO DONAIRE, J. A., NAVARRO RODRÍGUEZ, P., La reforma del régimen jurídico de la administración local. El nuevo marco regulatorio a la luz de la ley de racionalización y sostenibilidad de la administración local, La ley-El Consultor, Madrid, 2014.

CASADO CASADO, L., “Las competencias ambientales de las entidades locales: luces y sombras tras la Ley 27/2013, de 27 de diciembre, de racionalización y sostenibilidad de la Administración local”, Revista Aranzadi de Derecho Ambiental, núm. 32, dedicado a Homenaje a D. Ramón Martín Mateo (III), 2015.

CASSESE, S., Derecho Administrativo: historia y futuro, INAP, Global Law Press, Madrid, 2014.

CATALANO, M., "La legge anticorruzione”, DPA, núm 4, 2012.

CEBRIÁN ABELLÁN, M., El régimen local tras la reforma de la Ley de racionalización y sostenibilidad, Bosch -Wolters Kluwer, 2014.

CERRILLO I MARTÍNEZ, A., "Transparencia administrativa y lucha contra la corrupción en la Administración local”, en FONT LLOVET, T., GALÁN GALÁN, A., Anuario de Gobierno Local 2011. Gobierno Local: ¿crisis o renovación?, Fundación Democracia y Gobierno local, Madrid, abril 2012.

COCCIOLO, E. E., “Corruption control System.Beyond repression: regulation public integrity”, en BALLBÉ, M. ZAGANJORI, X., Comparative view of Administrative Law Issues, AECID, 2010.

COCCIOLO, E. E., "Las mutaciones del concepto de corrupción. De la ambigüedad de las sociedades arcaicas a la complejidad en la época del Estado regulador y de la sociedad del riesgo", Revista de Llengua i Dret, núm. 50, 2008.

COCCIOLO, E. E., et al., "Els controls i la bona administración”, en MOLES PLAZA, R. J., y COCCIOLO, E. E., Anàlisi dels elements del bon govern local. Codi del bon govern local, ACM, Barcelona, 2011.

COCCIOLO, E. E., REQUEJO GARCÍA, J., “L'ocupació pública a les administracions locals: la difícil relació entre principis i praxis”, en MOLES PLAZA, R. J., y COCCIOLO, E. E., Anàlisi dels elements del bon govern local. Codi del bon govern local, ACM, Barcelona, 2011.

CODARRI, P., SUSIO, B., “Lecco. II comune è in azione per i piani anticorruzione”, Archivio Penale, núm. 2, 2013.

CONSEJO DE EUROPA, Informe sobre la democracia local y regional en España, aprobado en la $24^{a}$ sesión plenaria, Estrasburgo, 20 de marzo de 2013.

COSITAL, Código ético profesional de los secretarios, interventores y tesoreros de administración local, VI asamblea, Salamanca, 12-14 de mayo de 2005.

COSMAI, P., "Il vademecum di Palazzo Vidoni sul responsabile della prevenzione della corruzione e le linee guida del comitato interministeriale”, A-P, núm. 4, 2013.

CSITAL Barcelona, Compromesos amb l’autonomia local, Declaración de la Asamblea de Sant Cugat el Vallès, 28 de noviembre de 2014.

CUENCA CERVERA, J. J., La difícil institucionalización de la democracia local en España: la pervivencia del legado histórico, IX Congreso, Asociación Española de Ciencia Política y de la Administración (AECPA), Málaga, septiembre, 2009.

DAVID, D., LEPORE, V., “La legge anticorruzione: novità e limiti applicativi negli enti locali”, Amministrazione in Cammino, 5 de julio de 2013.

DE LA NUEZ SÁNCHEZ-CASCADO, E., “Uno de los nuestros”, El Mundo, 7 de agosto de 2012.

DÍAZ LEMA, J. M., “El anteproyecto de Ley de Racionalización y Sostenibilidad de la Administración Local ¿Cambio de rumbo en la Administración española?”, en FONT LLOVET, T., GALÁN GALÁN, A. (dirs.), Racionalización y sostenibilidad de la Administración local: ¿es esta la reforma? Anuario de Gobierno Local 2012, Fundación Democracia y Gobierno local, Madrid, 2013.

DI SERI, Ch., “L'aggiornamento dei programmi triennali per la trasparenza e l’integrita' secondo il D.lgs. n. 33/2013 - II commento", GDA, núm.1, 2014.

DOLCINI, E., “Appunti su corruzione e legge anti-corruzione”, Rivista Italiana di Diritto e Procedura Penale (RIDPP), núm.2, 2013.

D'URGOLO, G., “Legge anticorruzione: oneri di pubblicità, disciplina degli incarichi extra-istituzionali, responsabilità erariale e responsabilità dirigenziale”, LexItalia.it (LI.it), núm.1, 2013. 
FIDONE, G., “Eficacia y eficiencia en la reforma italiana de la Administración pública (La Ilamada Reforma Brunetta)", RAP, núm. 186, Madrid, septiembre-diciembre, 2011.

FLORES DOMÍNGUEZ, L. E., “La reordenación del sector público local”, QDL, núm. 34 extraordinario, Fundación Democracia y Gobierno Local, Madrid, febrero, 2014.

FOÀ, S., "Le novità delle legge anticorruzione", Urbanistica e appalti (UA), núm 3, 2013.

FONT LLOVET, T., GALÁN GALÁN, A. (dirs.), Anuario del Gobierno Local 2013 ¿Un nuevo gobierno en España? La reforma de la Administración local en la Ley 27/2013, Fundación Democracia y Gobierno Local, Barcelona, junio, 2014.

FONT LLOVET, T., GALÁN GALÁN, A., “Gobierno local y reorganización: ¿la reforma vendrá de Europa?”, en FONT LLOVET, T., GALÁN GALÁN, A. (dirs.), Anuario de Gobierno Local 2011. Gobierno Local: ¿crisis o renovación?, Fundación Democracia y Gobierno local, Madrid, abril 2012.

FORCADELL I ESTELLER, X., “Aproximación crítica a los principales cambios en la legislación de régimen local como consecuencia de la aprobación de la Ley 27/2013, de 27 de diciembre, de racionalización y sostenibilidad de la Administración Local”, SANTAMARÍA PASTOR, J. A., (Coord.), La reforma de 2013 del régimen local español, Fundación Democracia y Gobierno Local, Madrid, 2013;

FORCADELL I ESTELLER, X., SABATÉ I VIDAL, J. M., (coords.), La reforma local. Reptes i oportunitats davant dels projectes de reforma del règim local impulsats pel govern estatal i el govern de la Generalitat, Barcelona, 2013.

FORCADELL ESTELLER, X., PIFARRÉ ESTRADA, M., SABATÉ I VIDAL, J. M. (coords.), Els governs locals de Catalunya davant la reforma del règim local espanyol, Parlament de Catalunya, Barcelona, 2014.

FRANCISCUS, Misericordiae Vultus, Bula de convocatoria del Jubileo Extraordinario de la Misericordia, Roma, 11 de abril de 2015, núm. 19.

FUENTES I GASÓ, J. R., “Buenas prácticas y códigos de conducta: ¿Sustitutivos de la legislación?”, Speyerer Forchungsbericte, núm. 201, 2015, págs. 144-145. .- "Consecuencias de la Ley 27/2013, de Racionalización y Sostenibilidad de la Administración Local en el régimen local de Cataluña", Revista Vasca de Administración Pública (RVAP), núm. 101, abril-mayo 2015, págs. 55-88..- "Gobiernos locales, retos de futuro", Revista Democracia y Gobierno Local (RDGL), núm. 29, segundo trimestre, 2015..- "El règim local de Catalunya i la viabilitat d'articulació d'una planta política i administrativa propia després de la sentencia del Tribunal Constitucional de 28 de juny de 2010", Revista catalana de dret públic, núm. Especial Sentencia 31/2010 del Tribunal Constitucional sobre el Estatuto de Autonomía de Cataluña de 2006), 2010..- FUENTES I GASÓ, J. R., GIFREU I FONT, J., RENYER I ALIMBAU, J., SABATÉ I VIDAL, J. M., Introducció al dret local i urbanístic de Catalunya, Tirant lo Blanch, Valencia, 2009.

FUEYO BROS, M., "Fortalecimiento de la figura del interventor. Función interventora y control interno: el control esvanecido”, en CARRILLO DONAIRE, J. A., NAVARRO RODRÍGUEZ, P., La reforma del régimen jurídico de la administración local. El nuevo marco regulatorio a la luz de la ley de racionalización y sostenibilidad de la administración local, La ley-El Consultor, Madrid, 2014.

GALÁN GALÁN, A., La reordenación de las competencias locales: duplicidades de Administraciones y competencias impropias, Fundación Democracia y Gobierno Local, Series: Debates Locales 3, Madrid, 2013

GARCÍA GARCÍA, M., J., “Los principios constitucionales de igualdad, mérito y capacidad: su plasmación en el Estatuto del Empleado Público”, Revista Jurídica de Castilla y León, núm. 15, mayo 2008.

GARCÍA RUBIO, F. (dir.) Análisis de las repercusiones de la reforma local sobre la organización, competencias y servicios de las entidades locales, INAP, Madrid, 2015. .- "La iniciativa económica local tras la ley 27/2013, de 27 de diciembre, de racionalización y sostenibilidad de la administración local", Revista de Estudios de la Administración Local y Autonómica (REALA), núm. 3, enero-junio, 2015. .- "La provincia como entidad local. Un análisis tras la Ley de Racionalización”, en SANTAMARÍA PASTOR, J. A., (coord.), La reforma de 2013 del régimen local español, Fundación Democracia y Gobierno Local, Madrid, 2014..- "Las entidades supramunicipales en el Gobierno local español. Reflexiones tras la reforma de la sostenibilidad”, QDL, núm. 34 extraordinario, Fundación Democracia y Gobierno Local, Madrid, febrero, 2014.

GIFREU I FONT, J., (Coord.), Introducció al Dret Local de Catalunya, Cedecs Editorial, Barcelona, 2002.."Presentació” de ZAFRA VÍCTOR, M., "Reordenación de las competencias municipales, entre la eficacia y la democracia”, en FORCADELL I ESTELLER, X., SABATÉ I VIDAL, J. M., (coords.), La reforma local. Reptes i oportunitats davant dels projectes de reforma del règim local impulsats pel govern estatal i el govern de la Generalitat, Barcelona, 2013.

GIFREU I FONT, J., FUENTES I GASÓ, J. R., Règim jurídic dels governs locals de Catalunya, Tirant lo Blanch, Valencia, 2009.

GIUPPONI, T. F., “Il contrasto alla corruzione a cavallo tra due legislature”, Quaderni costituzionali, núm 6, 2013.

GONZÁLEZ LÓPEZ-VALCÁRCEL, B., JIMÉNEZ GONZÁLEZ, J. L., PERDIGUERO GARCÍA, J., Danger: local corruption is contagious!, Mimeo, 2014. 
GONZÁLEZ PÉREZ, J., La ética en la Administración Pública, 2a. ed., Madrid, Civitas, 2000.

GUTIÉRREZ COLOMINA, V., LLAVADOR CISTERNES, H., (coord.), Ley de Racionalización y Sostenibilidad de la Administración Local. Estudio sobre la aplicación de la ley 27/2013, de 27 de diciembre, Tirant lo Blanch, Valencia, abril, 2015.

HURTADO LÓPEZ, G., "El rediseño y redimensionamiento del sector público económico local”, SANTAMARÍA PASTOR, J. A., (Coord.), La reforma del 2013 del régimen local español, Fundación Democracia y Gobierno Local, Madrid, 2014.

INAP - MHAP, Informe sobre el nuevo Régimen jurídico de los Funcionarios de Administración Local con Habilitación de carácter Nacional, establecido en la Ley 27/2013, de 27 de diciembre, 28 de mayo de 2015.

IZRAELI, D., BAR NIR, A., "Promoting ethics through Ethics Officers: a proposed profile and an application", Journal of Business Ethics, núm.17, 1998.

JIMÉNEZ ASENSIO, R., “El Proyecto de ley de Racionalización y Sostenibilidad de la Administración Local: novedades más relevantes en relación con los borradores del ARSAL y principales enmiendas aprobadas en el Congreso de los Diputados" (I y II), Diario del Derecho Municipal, 27 y 28 de noviembre de 2013.

JIMÉNEZ GONZÁLEZ, J. L., “La corrupción local en España”, Cuadernos económicos de ICE, núm. 85, junio, 2013.

JORDANO FRAGA, J., "Grietas en los ejes del modelo constitucional: las funciones reservadas a funcionarios", Revista Española de Derecho Administrativo (REDA), octubre-diciembre, 2015, págs. 151-186.

LADDAGA, G., “La PA dopo la legge anticorruzione”, Guida al pubblico impiego (GPI), núm. 5, 2013.

LÓPEZ GARCÍA MARTÍNEZ, A., "El fortalecimiento de la intervención local y la garantía de un mejor control interno económico-financiero y presupuestario en RODRíGUEZ-ARANA MUÑOZ, J., SARMIENTO ACOSTA, M. J., (dirs.), Comentarios a la Ley27/2013, de 27 de diciembre, de racionalización, sostenibilidad de la administración local, Comares, Granada, 2014.

MACRì, M., "Le misure urgenti sulla Pubblica Amministrazione - Le nuove disposizioni in materia di lavoro pubblico, GDA, núm. 11, 2014.

MARTÍNEZ MARÍN, A. Funcionarios locales con habilitación. Pasado, presente y futuro, Tecnos, Madrid, 1999..- “La reforma 2003 de los funcionarios locales con habilitación estatal”, Revista de Estudios de la Administración Local (REAL), núm 291, enero-abril, 2003..- "La reforma de 2003 de los funcionarios locales con habilitación nacional, REALA, núm. 291, 2003.

MARTÍNEZ PABLO, M., H., "La racionalización y sostenibilidad del nuevo régimen jurídico de los funcionarios con habilitación de carácter nacional tras la entrada en vigor de la Ley 27/2013, de 27 de octubre”, en GARCíA RUBIO, F. (dir.) Análisis de las repercusiones de la reforma local sobre la organización, competencias y servicios de las entidades locales, INAP, Madrid, 2015.

MASSA, O., "Lo chassé-coisé della retroattività (in margine alla “legge Severino")", Archivio Penale, núm. 1, 2014. MATTARELLA, B. G., "La prevenzione della corruzione in Itaia - Il commento”, GDA, núm. 2, 2013.

MEDINA GUERRERO, M., La reforma del régimen local, Tirant lo Blanch, Valencia, 2014..- "La reforma del régimen local: una honda transformación de las relaciones intergubernamentales”, QDL, núm. 34 extraordinario, Fundación Democracia y Gobierno Local, Madrid, febrero, 2014.

MELE, R., STORLAZZI, A., "La funzione di direzione generale nel Comune: il ruolo del segretario comunale”, Azienda Pubblica (AP), 5, 1997.

MELLADO RUÍZ, L., Génesis y realidad de la ley 27/2013, de 27 de diciembre, de racionalización y Sostenibilidad de la administración local: ¿una nueva reforma económica local?, CEMCI, Granada, 2014..- "Notas críticas sobre el Anteproyecto de Ley para la racionalización y sostenibilidad de la Administración Local. Entre la reforma y la intervención", Revista CEMCI, núm. 17, 2012.

MEOLA, A., "Il ruolo del segretario nei nuovi controlli interni degli enti locali tra management, legalità e civil servants", Azienditalia, núm. 3, pag. 2013.

MEOLI, C., “I segretari comunali e provinciali: dall’Agenzia di nuovo al Ministero dell'interno (comm. a d.I. 31 marzo 2010, n. 78)", GDA, núm. 17, 5, 2011.

MERLONI, F., “I piani anticorruzione e i codici di comportamento”, DPA, núm. 8, 2013.

MIR I BAIGÓ, J., “El debat sobre la reforma del govern local a Catalunya”, Seminari de Dret local, Federació de Municipis de Catalunya, Barcelona, 2013

MONTALBO LOBO, L., "La nueva posición de los funcionarios de administración local con habilitación de carácter nacional”, en RODRíGUEZ-ARANA MUÑOZ, J., SARMIENTO ACOSTA, M. J., (dirs.), Comentarios a la Ley27/2013, de 27 de diciembre, de racionalización, sostenibilidad de la administración local, Comares, Granada, 2014 .

MONTOYA MARTÍN, E., "Medidas de redimensionamiento del sector público instrumental local antes y después de la Ley 27/2013, de 27 de diciembre, de racionalización y sostenibilidad de la Administración Local”, Revista General de Derecho Administrativo (RGDA), núm. 36, mayo 2014. 
MUÑOZ MACHADO, S., “Reflexiones sobre la pretendida reforma del régimen local”. Diario de Derecho Municipal, 10 de junio de 2013.

NAVARRO RODRÍGUEZ, P., ZAFRA VÍCTOR, M., “El pretendido blindaje autonómico de las competencias municipales tras la reforma de la Administración local”, REALA, núm. 2, julio-setiembre, 2014.

NIETO GARCÍA, A., El desgobierno de lo público, Ariel, Barcelona, 2008.

NIGLIO, N., "La prevenzione del fenomeno della corruzione nella P.A., alla luce della legge n. 190/2012. (Una prima riflessione sui primi 59 commi dell'articolo 1, della legge 6 novembre 2012, n. 190)", LI.it, núm.1, 2013.

ORDUÑA REBOLLO, E., "Historia de una profesión al servicio de la ciudadanía: secretarios, interventores y tesoreros de la administración local española”, ORDUÑA REBOLLO, E., MERINO ESTRADA, V. (coord.), Secretarios, interventores y tesoreros de la administración local: doscientos años al servicio de la ciudadanía, Consejo General de Colegios de Secretarios, Interventores y Tesoreros de Administración Local (COSITAL), Madrid, 2012.

PANASSIDI, G., “Alcune riflessioni critiche sulle figure di vertice dell’organizzazione amministrativa dei comuni e delle province: segretario comunale e direttore generale", Giustamm., núm. 4, 2001.

PAREJO ALFONSO, L., "Algunas reflexiones sobre el impacto de la Ley 27/2013, de 27 de diciembre, sobre el modelo de autogobierno municipal”, QDL, núm. 34 extraordinario, Fundación Democracia y Gobierno Local, Madrid, febrero, 2014..- "El principio de legalidad, la Administración local y las funciones públicas colocadas en ella al servicio de aquél”, en ORDUÑA REBOLLO, E., MERINO ESTRADA, V. (coord.), Secretarios, interventores y tesoreros de la administración local: doscientos años al servicio de la ciudadanía, Consejo General de Colegios de Secretarios, Interventores y Tesoreros de Administración Local (COSITAL), Madrid, 2012.

PELISSERO, M., “'Nuove' misure di contrasto alla corruzione?”, Diritto penale e processo (DPP), núm. 1, 2015.

PÉREZ-FRANCESCH, J. L., COCCIOLO, E., EYRE de LORENZO, J. A., “Disolución de los Ayuntamientos en España y corrupción sistémica. Aproximación al ‘Caso Marbella’ y comparación con la normativa italiana en materia de disolución en supuestos de emergencia extraordinaria”, REALA, núm. 305, 2007.

PERIN M., "Legge anticorruzione e gli obblighi del responsabile della prevenzione della corruzione con riferimento alla lesione dell'immagine pubblica", Ll.it, núm.1, 2013.

PICADO SOTELA, S., “Ética pública y corrupción” en AA.VV., El derecho público a comienzos del siglo XXI. Libro Homenaje al Prof. Brewer Carías, Thomson-Civitas, Vol. III, Madrid, 2003.

PUJOL I ESTRAGUÉS, H.; RIBA I TORRALBA, J., Els directius públics. Aproximació al seu perfil i a les seves necessitats formatives, Escola d'Administració Pública de Catalunya. Barcelona, 1996.

QUADRELLI, M., "Natura giuridica della Civit, principio del buon andamento e piano triennale di prevenzione della corruzione”, LI.it, núm.9, 2013.

QUINTANA LÓPEZ, T. et alter, La reforma del régimen local. Comentario a la ley 27/2013, de 27 de diciembre, de racionalización y sostenibilidad de la administración local, Tirant lo Blanch, Valencia, 2014.

QUINTERO OLIVARES, G., FRANQUET SUGRAÑES, M. T., “Estado, mercado y Constitución: la dimensión penal”, en QUINTERO OLIVARES, G., (dir.), JARIA MANZANO, J., (coord.), Derecho Penal Constitucional, Tirant lo Blanch, Valencia, 2015.

RENYER I ALIMBAU, J., FUENTES I GASÓ, J. R., SOTO VALLE, J., I, FORCADELL I ESTELLER, X., Estudis per a una Llei de Governs Locals de Catalunya (2007-2011), Tirant lo Blanch, Valencia, 2011.

RIVERO ORTEGA, R., Instituciones administrativas, desarrollo y control de la corrupción. El caso colombiano, Unión Iberoamericana de Municipalistas, Madrid, 2006..- "La evolución histórica de los servicios públicos locales y el papel de los habilitados desde la Constitución de Cádiz hasta nuestros días”, en ORDUÑA REBOLLO, E., MERINO ESTRADA, V. (coord.), Secretarios, interventores y tesoreros de la administración local: doscientos años al servicio de la ciudadanía, Consejo General de Colegios de Secretarios, Interventores y Tesoreros de Administración Local (COSITAL), Madrid, 2012..- "Oportunidades, riesgos y resultados reales de la Ley de racionalización y sostenibilidad de la Administración Local” en Revista de Administración Local i Autonómica (REALA), núm. extraordinario, enero, 2015.

RIVERO YSERN, E.; RODRÍGUEZ-ARANA MUÑOZ, J., Con miras al interés general, Derecho Público Global, Madrid, 2014.

RODRÍGUEZ BEAS, R., FUENTES I GASÓ, J. R., “La organización territorial del Estatuto de 2006 y el impacto de la Ley 272013, de Racionalización y Sostenibilidad de la Administración Local en al interiorización del régimen local de Cataluña”, en GARCÍA RUBIO, F., Análisis de las repercusiones de la reforma local sobre la organización, competencias y servicios de las entidades locales, INAP, Madrid, 2015.

RODRÍGUEZ-ARANA MUÑOZ, J., "El derecho a la buena administración en las relaciones entre ciudadanos y administración pública", Anuario da Facultade de Dereito da Universidade da Coruña (AFDUC), núm. 16, 2012.

RODRÍGUEZ-ARANA MUÑOZ, J., SARMIENTO ACOSTA, M. J., (dirs.), Comentarios a la Ley27/2013, de 27 de diciembre, de racionalización, sostenibilidad de la administración local, Comares, Granada, 2014. 
ROSI, E., "Corruzione transnazionale e/o corruzione internazionale: una breve riflessione", DPP, 2013.

ROSSI, A., "I piani per la prevenzione della corruzione in ambito pubblico ed i modelli 231 in ambito privato", DPP, núm. 8, 2013.

ROSSI, C., "Il segretario comunale, riedizione moderna del mito di Atlante", LeggiOggi.it, 4 de julio de 2012.

RUFFINI, R., "L'evoluzione del sistema dei controlli interni negli enti locali alla luce della legge n. 190/2012 in tema di corruzione", A-P, núm.1, 2013.

SABATÉ I VIDAL, J. M., "El impacto de la Ley 27/2013, de 27 de diciembre, de racionalización y sostenibilidad de la Administración local, en el régimen de las diputaciones provinciales y entes equivalentes", en FONT LLOVET, T., GALÁN GALÁN, A. (dirs.), Anuario del Gobierno Local 2013 ¿Un nuevo gobierno en España? La reforma de la Administración local en la Ley 27/2013, Fundación Democracia y Gobierno Local, Barcelona, junio, 2014.

SABATÉ VIDAL J. M., "Una perspectiva local de la Ley 19/2013, de transparencia, acceso a la información pública y buen gobierno", en FONT I LLOBET, T., GALÁN GALÁN, A., Anuario del Gobierno Local 2014-Los retos del Gobierno local: repolitización, transparencia y reformas, Fundación Democracia y Gobierno Local, Madrid, 2015.

SALAZAR BENÍTEZ, O., “La autonomía local devaluada: La dudosa 'racionalidad' de la Ley 27/2013, de 27 de diciembre, de racionalización y sostenibilidad de la Administración local”, Teoría y Realidad Constitucional, UNED, núm.34, 2014.

SÁNCHEZ BLANCO, A., "La función pública de los Secretarios e Interventores de la Administración local”, REALA, núm. 291, 2003.

SÁNCHEZ MÓRON, M., "El impacto de la reforma de la Administración local en el empleo público", en FONT LLOVET, T., GALÁN GALÁN, A., Anuario del Gobierno Local 2013 ¿Un nuevo gobierno local en España? La reforma de la Administración local en la Ley 27/2013, Fundación Democracia y Gobierno local, Barcelona, junio 2014.

SANDULLI, M, A., "Le nuove misure di deflazione del contenzioso amministrativo: prevenzione dell'abuso di processo o diniego di giustizia?", Foro Amministrativo-T.A.R. (II), núm. 9, 2012.

SANTAMARÍA PASTOR, J. A., (coord.), La reforma de 2013 del régimen local español, Fundación Democracia y Gobierno Local, Madrid, 2014.

SERRANO PASCUAL, A., "El régimen jurídico de los funcionarios con habilitación de carácter estatal", El Consultor de los Ayuntamientos y los Juzgados, núm. 24, 2008-2009.

SEVERINI, "La presunta incostituzionalità del Decreto Severino: tattica dilatorio o dubbio non manifestamente infondato?, en Osservatorio dell'Associazione Italiana dei Costituzionalisti, octubre, 2013.

SEVERINI, "La presunta incostituzionalità del Decreto Severino: tattica dilatorio o dubbio non manifestamente infondato?, Osservatorio dell'Associazione Italiana dei Costituzionalisti, octubre, 2013.

SILVESTRO, C., "Il fluttuante orientamento attorno la figura del city manager", Diritto\&Diritti, febrer, 2002.

SORGENTE, N., "Il rafforzamento del sistema dei controlli interni negli enti locali alla luce del D.L. 174/2012 e i suoi riflessi sullo status del segretario comunale.", Rivista Giuridica AmbienteDiritto.lt, 2012.

SOSA WAGNER, F., "Penalistas y Ayuntamientos", El blog de esPublico, 11 de diciembre de 2007..-, "Prólogo", en CARRILLO DONAIRE, J. A., NAVARRO RODRÍGUEZ, P., La reforma del régimen jurídico de la administración local. El nuevo marco regulatorio a la luz de la ley de racionalización y sostenibilidad de la administración local, La ley-El Consultor, Madrid, 2014.

TESTA, V., "Anticorruzione: come individuare il responsabile della prevenzione", GPI, núm. 3, 2013. ."Anticorruzione: in pubblica consultazione le linee guida per l'adozione dei codici di comportamento", GPI, núm. 10, 2013..- "Approvato il Piano nazionale anticorruzione. Ora tocca alle amministrazioni", GPI, núm. 10, 2013.

TOCQUEVILLE, A. de, La democracia en América, vol. I, París, 1835.

TOSCANO GIL, F., "El nuevo sistema de competencias municipales tras la Ley de racionalización y sostenibilidad de la administración local: competencias propias y competencias distintas de las propias y de las atribuidas por delegación", Revista española de derecho administrativo (REDA), núm. 165, 2014.

TOSCAS SANTAMANS, E., "Las nuevas normas sobre los secretarios de los ayuntamientos en España: un ejemplo de desregulación de la función pública”, Scripta Nova, Revista Electrónica de Geografía y Ciencias Sociales, vol. XII, núm. 270 (34), 2008.

TOSCAS SANTAMANS, E., AYALA DOMÈNECH, F., "De las relaciones centro-periferia en el Estado liberal. Gobernadores civiles, ayuntamientos y secretarios municipales en la España del Ochocientos", El Consultor de los Ayuntamientos, núm.5, año 2010.

TUBERTINI, C., “La legge 'Delrio': il riordino del governo locale - ILe norme in materia di unioni e fusioni”, GDA, núms. 8-9, 2014.

TURRINI, D., "PA, i segretari comunali contro il governo: No all'albo unico con i direttori generali", Il Fatto Quotidiano, 27 de junio de 2014. 
URQUIZA MORALES, J. M., Corrupción municipal. Por qué se produce y cómo evitarla, Almuzara, Córdova, 2005.

VANDELLI, L., "La participación de los entes locales en las regiones”, en FONT LLOVET, T., GALÁN GALÁN, A., (dirs.), Anuario de Gobierno Local 2008, Fundación Democracia y Gobierno Local, Madrid, 2009.

VELASCO CABALLERO, F., "El nuevo régimen local general y su aplicación diferenciada en las distintas comunidades autónomas", Revista catalana de dret públic (RCDP), núm. 48, 2014. .- "Nuevo régimen de competencias municipales en el Anteproyecto de Racionalización y Sostenibilidad de la Administración Local", Anuario de Derecho Municipal 2012, núm. 6, 2013..- "Títulos competenciales y garantía constitucional de autonomía local en la Ley de Racionalización y Sostenibilidad de la Administración Local”, SANTAMARÍA PASTOR, J. A., (coord.), La reforma de 2013 del régimen local español, Fundación Democracia y Gobierno Local, Madrid, 2014.

VERA TORRECILLAS, R, “Las funciones reservadas y el Estatuto Básico del Empleado Público: algunas consideraciones sobre la reforma de los Funcionarios de Habilitación Estatal”, El Consultor de los Ayuntamientos y de los Juzgados, núm. 9, 2009.

VERBARO, F., "Quella legge anticorruzione tanto attesa quanto poco efficace”, GPI, núms.1-2, 2013; “II "peso” della formazione nella lotta alla corruzione", GPI, núm. 3, 2013.

VILLORIA MENDIETA, M.; JIMÉNEZ SÁNCHEZ, F., “La corrupción en España (2004-2010): datos, percepción y efectos", REIS, núm. 138, abril-junio 2012.

VIÑAS BOSQUET, J., P., "Fundamentos, contenido y derecho comparado del control interno en las entidades locales, REALA, núm. 296-297, 2004-2005.

VIVANCOS COMES, M., “Reflexiones apresuradas sobre la reforma local en ciernes”, Corts. Anuario de Derecho Parlamentario, núm. 27, 2013.

ZAFRA VÍCTOR, M., "Esta reforma local empobrece la democracia”, El País, 1 de agosto de 2013..- "Reordenación de las competencias municipales, entre la eficacia y democracia”, en FORCADELL I ESTELLER, X., SABATÉ I VIDAL, J. M., (coords.), La reforma local. Reptes i oportunitats davant dels projectes de reforma del règim local impulsats pel govern estatal i el govern de la Generalitat, Barcelona, 2013. 
